\title{
COMPULSORY ACQUISITION OF THE INTEREST OF A DISSENTING MINORITY SHAREHOLDER
}

\author{
A. MAURICE FLISFEDER*
}

The problem of a dissenting minority in a take-over draws into focus wider issues relating to the nature of corporate organization and the respective rights and obligations of shareholders, as well as the position of the courts in any conflict which may arise. The author examines the Anglo-Canadian approach of compulsory acquisition, with its prerequisite of the forced sale being "bona fide in the interests of the company as a whole". This is contrasted to the American approach of charter alteration, share redemption, merger, sale of assets to a new corporation, and, perhaps more important, the right to appraisal of shares. It is sug. gested that the Anglo-Canadian approach of compulsory acquisition is a more convenient method of eliminating a dissenting minority than that used in the United States, but that Canada should incorporate the right of appraisal of the American system, and thereby obtain the benefits of both systems.

\section{THE POSITION IN ANGLO-CANADIAN LAW}

\section{Introduction}

In this paper I propose to discuss the compulsory acquisition of the shares of a minority shareholder, beginning with the common law ${ }^{1}$ position, and tracing its evolution to the present. Thereafter I will explore the statutory provision requiring a dissenting minority to sell its shares in a take-over, starting with the background and raison d'etre of this provision. Although concerned primarily with statutes of Great Britain, Australia, New Zealand, and Canada (including its Provinces), this paper will also refer to the law of other jurisdictions.

The case law will then be analyzed to determine whether the intention of the statute is being carried out, as well as whether or not the law should be changed, and, if so, in what respects. Finally, after considering the Anglo-Canadian position, I will look at the American situation, and will attempt to show that the convenience of the former approach can be combined with the more equitable approach of the latter to form a more useful, fair and workable system.

\section{Compulsory Acquisition at Common Law}

The common law position is of interest for a number of reasons. Firstly, it shows that there are cases where even at common law it was equitable to expropriate the shares of a minority shareholder. Secondly, in deciding the cases the courts have propounded a test which, to an extent, is still being used today under the statutory provisions. Thirdly; as not all jurisdictions have enacted statutory provisions, it may be of importance to see when the common law position can be relied upon.

\section{The Right to Alter Articles of Association}

Before considering the expropriation cases themselves, the law as regards the right of a company to alter its articles of association (or letters patent and by-laws) and the effect which this change has on

- B.C.L., LL.B., LL.M.

'The term "common law" is used rather loosely since the principles involved in the earlier cases also depend to a large extent on various statutory provisions. 
the shareholders, must be examined. In fact, the question of "expropriation" of shares by means of altering the articles of association is essentially a special case of the problem relating to altering articles of association. This, in turn, is one of the exceptions to the rule in Foss v. Harbottle. ${ }^{2}$

The test as to whether the articles of association have been validly altered is stated in the leading case of Allen v. Gold Reefs of West Africa, $L t d .^{3}$ Here Lindley M.R. laid down as the criterion for the use of the power to alter articles of association that it be exercised "bona fide for the benefit of the company as a whole". ${ }^{4}$ This principle has been followed in subsequent cases ${ }^{5}$ dealing with the alteration of articles of association. As all the English cases deal with the alteration of articles of association, the question arises, in letters patent jurisdictions, as to whether the same principle applies to the amendment of company bylaws. The trend at present seems to be to apply these cases to letters patent situations without noting that there is the underlying difference that articles of association are based on a contractual concept. ${ }^{6}$ Indeed, Wegenast goes further and states that the same principle would apply to the issuing of supplementary letters patent. ${ }^{7}$

\section{The Jurisprudence of Compulsory Acquisition at Common Law}

As regards the question of expropriation of shares, a number of English cases have dealt with the question of whether the majority shareholders could force the minority to sell their shares to the majority. ${ }^{8}$ In Brown v. British Abrasive Wheel Co. ${ }^{9}$ the company was in need of additional capital which the majority, who formed ninety-eight per cent,

2 (1843) 2 Hare 461, 67 E.R. 189. The rule states that if any wrong is done to a corporation only the corporation itself can sue. The case of fraud on the minority by means of altering the articles of association is not really an exception to the rule but a case where the rule has no application at all. For a discussion of this principle see: Beck, An Analysis of Foss $v$. Harbottle, in Studies in Canadian Company Law 545 (1967, ed. J. S. Ziegel); McPherson, Limits of Fraud on the Minority, (1960) 77 S.A.L.J. 297, and Wedderburn, Share. holders' Rights and the Rule in Foss v. Harbottle, (1957) Camb. L.J. 194, (1958) Camb. L.J. 93.

[ [1900] $1 \mathrm{Ch}$. 656, varying [1899] $2 \mathrm{Ch}$. 40. Here the Court had to consider whether the articles could be amended to allow a lien on fully paid up shares as well as non-fully paid up shares as previously had been the case.

- [1900] 1 Ch. 656 at 671 . A test of good faith in the interests of the company had previously been used in company law, see Re Bell Bros. Ltd. (1891) 65 L.T. 245, a case dealing with the refusal to register a transfer of shares.

s Shuttleworth v. Cox Brothers and Comapny (Maidenhead) Ltd. [1927] 2 K.B. 9(C.A.), where the question of whether a permanent director could be removed was dealt with; Greenhalgh v. Arderne Cinemas, Ltd. [1951] Ch. 287 (C.A.), where the issue was whether the pre-emptive rights of existing shareholders could be changed to allow a sale to an outsider, Right and Issues, Investment Trust Ltd. v. Stylo.Shoes Ltd., and Others [1965] $1 \mathrm{Ch}$. 250 which involved the alteration of the relative voting power of various shares; Crookston v. Lindsay, Crookston \& Company Limited [1922] Scots L.T. 626 where an alteration required a shareholder who desired to sell his shares to first offer them to the directors at par; Australian Fixed Trust Pty. Ltd. v. Clyde Industries Ltd. (1959) 59 S.R. (N.S.W.) 33 in which alteration was refused where it would make it difficult or impossible for shares owned by the trust ever to be voted. (See a note on this case by Dorsch (1959-61) 3 Syd. L.R. 353 and one by Ford (1960) 2 Mel. L. Rev. 399); and Levin v. Felt \& Tweeds Ltd. [1951] 2 S.A. 401 where capital was reduced by redeeming preferred shares and money was borrowed on a mortgage to do this. It was held to be bona fide in the interests of the company. In Gundelfinger v. African Textile Manufacturers Ltd., and Others [1939] S.A. 314 the same test was applied to the vote by directors authorizing a payment by the company to the directors. See also Hogg v. Cramphorn Led. [1967] 1 Ch. 254 and Bamford v. Bamford |1970| 1 Ch. 212 (C.A.). For a recent article on the subject see Bretton, Alteration of Articles and Protection of Minorities, (1970) J. Bus. L. 185. Recommendations in the recent Canadian Company Law Report, Proposals for a New Business Corporation Law for Canada (Task Force Report), would solve this problem by giving the minority shareholder the right to have his shares bought out in cases of fundamental corporate changes. See the report Para. 347 at 115 .

6 Beck, An Analysis of Foss v. Harbottle, supra, n. 2, at 594.

7 Wegenast, The Law of Canadian Companies 321 (1931).

"See: Some Cases on the Power to Alter the Articles (1939) 83 Sol. J. 85 and Compulsory Transfer of Shares (1946) 90 Sol. J. 314.

- [1919] Ch. 290 per Astbury J. 
were willing to provide, if they could buy the shares held by the minority. They proposed to pass an amendment to the articles of association requiring the minority to sell their shares. The Court refused to sanction this amendment on the basis that it was not just or equitable or for the benefit of the company as a whole.

In Sidebottom v. Kershaw and Co. Ltd., ${ }^{10}$ the majority sought to alter the articles of a company in order to force any shareholder who competed with the company to sell his shares to the majority. The Court held that anything that could have been included in the original articles could be inserted by amendment provided, once again, it was "bona fide for the benefit of the company as a whole". Warrington L.J. pointed out that "bona fide" and "for the benefit of the company as a whole" were not two distinct tests. ${ }^{11}$ The fact that the power of expropriation could validly be included in the original articles of association had already been accepted in Phillips v. Manufacturers' Securities Ltd.12 What is surprising about the case is that upon the passing of a resolution under the articles the shares would be sold at a price fixed by the resolution, or failing that, at one shilling. Here the shares had in fact to be sold for one shilling, although their value was much greater. ${ }^{13}$

Shortly after the Sidebottom case, the Court in Dafen Tinplate Company Ltd. v. Llanelly Steel Co. (1907) Ltd. ${ }^{14}$ disallowed the alteration of the articles of association of the Llanelly Company, where the alteration would have allowed the majority of the shareholders to force the sale and set the price of the shares of any member. The basis of the Court's rejection of this change was that the power conferred on the majority was unrestricted in that they could, under the amendment, expropriate any member's shares at their will and pleasure and could also determine the price to be paid. The mere fact that they would only use the provision for the benefit of the company as a whole was not sufficient to make it valid if the power conferred could potentially be abused. In the Court's view the power appeared to have been conferred for the benefit of the majority of the shareholders rather than for the benefit of the company as a whole. ${ }^{15}$

Thus, as regards those cases where shares are expropriated by altering the articles of association to permit this, the question to be asked is whether the alteration was made "bona fide for the benefit of the company as a whole." This same test was restated in a different form in Greenhalgh v. Arderne Cinemas, ${ }^{16}$ where Evershed J. said the test

\footnotetext{
10 [1920] Ch. 154 (C.A.).

"In the earlier case of Borland's Trustee v. Steel Brothers \& Co. Ltd. [1901] 1 Ch. 279 per Farwell J. the amendment of the articles required a shareholder to transfer his shares to a particular person at a particular price. However, none of the shareholders disagreed with the amendment and the question only arose on the subsequent bankruptcy.

12 (1917) 116 L.T. 290 (C.A.). The same had been held in Blisset v. Daniel (1853) 10 Hare 493 per Sir W. Page Wood V.C. a case dealing with the articles of partnership. The court upheld a clause which allowed a partner to be expelled provided it was exercised bona fide for the benefit of the partnership as a whole. The principle here must be distinguished from the situation arising out of a compulsory buy-sell agreement between shareholders. In such a situation the power to force a sale arises by agreement between the shareholders and not from the agreement which forms the company itself.

13 In Phillips v. The Manufacturers' Securities (Ltd.) (1915) 31 T.L.R. 451 per Eve J. an injunction was granted preventing the company from requiring a member to sell his shares to other members.

" [1920] 2 Ch. 124 per Peterson J.

is The same principle has been applied in Fairham v. Cape Town Mutual Aid Fund [1949] 1 S.A. 919 per Ogilvie Thompson A.J. where the Court refused to allow an alteration to the constitution of a voluntary association which would abolish certain membership on the ground that it was not bona fide for the benefit of the association as a whole.

16 Supra, n. 5. See a note on the case A Snag in Table A, (1946) 90 Sol. J. 375 at 388.
} 
is whether the effect of the alteration is "to discriminate between majority shareholders and minority shareholders so as to give the former an advantage of which the latter was deprived". ${ }^{17}$ This formulation may prove useful in trying to relate the common law position to its statutory counterpart, and again when considering the American position. What must be remembered in these common law expropriation cases is that only a minority of the shareholders are displaced while the majority are the same, before and after the alteration. In the case of statutory expropriation it is an outside and independent majority who have acquired the majority shares. Thus, as stated, the common law position is of importance because it may serve as a guide when dealing with the statute. Furthermore, in those jurisdictions which have not enacted statutory provisions, the common law may be the only available means of disposing of an unwanted minority. The connection between the common law position and the statutory position has been summed up by Professor Gower: ${ }^{18}$

Unless the decisions in Brown's case and Dafen Tinplate are right, the statutory power seems to be unnecessary and the statutory safeguards unavailing, for the majority, even if less than nine-tenths, could attain their object by an alteration of the articles provided only that they could not be proved to have acted otherwise than "bona fide for the benefit of the company as a whole". Whatever may have been the position prior to 1929 , it is thought that the court will not today permit compulsory acquisition in disregard of the statutory rules unless, as in Sidebottom's case, the power is only exercisable in circumstances which are prima facie beneficial to the company.

From this two conclusions can be drawn. Firstly, that if a jurisdiction has enacted a statutory provision it must be followed..$^{19}$ Secondly, as will be seen, in almost all cases where the statute has a provision it applies only after one company takes over another by acquiring a certain proportion of its shares.

The general requirement discussed above speaks of benefit to the company as a whole. In a take-over situation two companies are involved, so it may be confusing to speak in terms of benefit to a company as a whole. ${ }^{20}$ If one takes the alternate view of not discriminating between majority and minority shareholders the question becomes more comprehensible. The take-over cannot be used to give the majority an advantage of which the minority is deprived. This will be referred to again when establishing a link between the statutory and common law cases.

\section{Legislative Development of the Right of Compulsory Acquisition}

One must now look to the development of the statutory law with respect to the compulsory acquisition of the shares of a dissenting minority shareholder. The statutory position involves the case where

17 Id. at 291.

18 Gower, The Principles of Modern Company Law 569 (3rd ed. 1969).

to Even if there is a statute it may not necessarily cover all cases. For example, as will be explained, most statutes deal with the case where one company takes over another but do not cover the case where an individual takes over a company. One may ask whether an individual could rely on the common law cases. Alternatively it may be that the statute must be strictly enforced and based on the maxim inclusio unius est exclusio alterius that only a company and not an individual can expropriate shares.

20 There is also some controversy as to whether the benefit to the company as a whole means the commercial entity or the shareholders. The writer takes the latter view as the goal is to protect the shareholders. Otherwise in a take-over situation the company taken over and maintained as a separate entity will prob ably benefit even in cases where the minority suffer. Indeed, in common law situations the company would probably have benefited by getting rid of the shareholders even in cases where this was not permitted. 
one company makes an offer to take over another and the offer is approved by ninety per cent of the shareholders, of the offeree company, within four months. The offeror company can at any time within two months of the approval notify the dissenting shareholders of its intention to acquire their shares. The dissenting shareholders then have one month to complain to the court. If they do not, the offeror is entitled and bound to acquire their shares on the same terms which the approving shareholders have accepted.21

The basis of the English legislation and, indeed, of all the jurisdictions which have similar provisions is paragraph eighty-four of the Greene Report. ${ }^{22}$ The final sentence sums up the reasons for the committee's recommendations: ${ }^{23}$

In our opinion this position which is in effect an oppression of the majority by a minority-should be met.

The committee's recommendations stemmed from a view that in some cases a minority may try to hold on to their shares in order to extract better terms than the other shareholders. This was the position which the committee felt should be met. It did not intend, by its silence on the matter, to sanction the opposite case of the oppression of the minority by the majority. It must be remembered that even if there are valid business and company law reasons for having such a statutory provision, it remains a means of expropriation. ${ }^{24}$

The paragraph points out that in some cases where one company takes over another it is essential that the acquired company continue its corporate existence. There may be some goodwill associated with the name of the company or it may hold some property such as a license or patent which cannot be transferred. It points out that the company may seek to acquire all the shares and would not otherwise enter into the transaction. Based on this proposal the section made its first appearance in England in the Company Amendment Act of $1928,{ }^{25}$ and

21 The sections under the various acts are as follows: Canada, The Companies Act, R.S.C. 1952, c. 53, s. 128 (The name of this act was changed to the Canada Corporations Act by an Act to Amend the Companies Act, S.C. $1964-65$, c. 52, 8. 2); Alberta, The Companies Act, R.S.A. 1970, c. 60, s. 153; British Columbia, Companies Act, R.S.B.C. 1960, c. 67, 8. 181; Nova Scotia, Companies Act, R.S.N.S. 1967, c. 52, 8. 119; Saskatchewan, The Companies Act, R.S.S. 1965, c. 131, 8. 189; Quebec, Companies Act, R.S.Q. 1964, c. 271, 88. 48 and 145 ; North West Territories, Companies Ordinance, Ordinances of North West Territories, 1968-First Session, c. 1, 8. 146; Manitoba formerly had such a provision which allowed for the compulsory acquisition once an offer had been accepted by three-quarters of the shareholders-The Companies Act, R.S.M. 1954, c. 43, s. 104; United Kingdom, Companies Act, 1948, 11 \& 12 Geo. 6, c. 38, s. 209; Australia, Uniform Companies Act, 8. 185; New South Wales, Companies Act 1961; Queensland, Companies Act 1961; South Australia, Companies Act 1962; Tasmania, Companies Act 1962; Victoria, Companies Act 1961; Western Australia, Companies Act 1961-62; Australian Capital Territory, Companies Ordinance 1962; Northern Territory, Companies Ordinance 1963; under the new Victorian version of the Australian Uniform Companies Act this would be replaced by 88 . $180 \mathrm{X}$ and $180 \mathrm{Y}$ which would apply to take-over offers governed by the specific take-over provision in the legislation by a ncw s. 185 in other cases); Republic of South Africa, Companies Act, Act No. 46 of 1926, 8. 103 as inserted by s. 65 of Act No. 23 of 1939 and amended by s. 86 of Act No. 46 of 1952 ; India, The Companies Act of 1956, Act No. 1 of 1956, 8. 395; New Zealand, Companies Act 1966, Act No. 63 of 1965, 8. 208.

22 Report of the Company Law Amendment Committee, Cmd. No. 2657, (1925-26).

23 For a general discussion of the law under the English section which also applies to those jurisdictions which have enacted similar provisions, see Weinberg, Take-Overs and Amalgamations 143 (2d ed. 1967).

24 The question of the constitutional validity of this section as regards the Canadian section was raised in Re Julius G. Day and Canadian International Paper Company (1949) 29 C.B.R. 230 (Quebec Superior Court in Bankruptcy). The Supreme Court of British Columbia in Rathie v. Montreal Trust Company [1952] 3 D.L.R. 61 held that the section dealt with company law and not property and civil rights and was valid federal legislation. This decision was upheld by the Court of Appeal of British Columbia [1952] 4 D.L.R. 448 and the Supreme Court of Canada [1953] 2 S.C.R. 204, although the latter did not discuss the issue. However, the constitutionality was upheld by the Supreme Court of Canada in Esso Standard (Inter. America) Inc. v. J. W. Enterprises [1963] S.C.R. 144 at 152-153.

2 Companies Act, 1928, 18 \& 19 Geo. 5, c. 45, 8. 50 . 
was subsequently incorporated into the Companies Act of $1929 .{ }^{26}$ It must be noted that under the legislation there is no guarantee that a company will always be able to acquire all the shares of a company being taken over, since a court has the power to order otherwise. Indeed, the problem is the too infrequent use of this power by the court.

When one looks at the specific recommendation itself, under paragraph eighty-five, it is seen that it speaks of a "purchasing concern"27 making the take-over. When the legislation was finally enacted, however, it spoke of a take-over of one company by another. If the goal is to prevent the oppression of a majority, why not include cases where an individual or a partnership buys out a company? ${ }^{28}$ This question will be enlarged upon when looking at the case law. What is even more surprising is that the legislation, in some cases, allows a company from outside the jurisdiction of the acquired company to force the minority to sell its shares. ${ }^{29}$ It seems rather strange that such a provision exists as it invites foreign take-overs and therefore creates an acute problem where a country is fighting against foreign take-overs. It would seem that such legislation should not allow for compulsory take-over by a foreign corporation. No jurisdiction would allow a foreign corporation to expropriate property within its jurisdiction and the same should apply to shares.

Lastly, if the goal of such legislation is to prevent the oppression of a minority, on what basis was the figure of ninety per cent chosen? ${ }^{30}$ This is not to imply that a lower figure should be selected, but rather that a unified approach to corporate reorganization may require that similar percentages of approval be used in all types of corporation reorganization.

It may be that legislation should be limited to apply only in those cases dealing with large public companies having many shareholders. ${ }^{31}$

However, many large companies are satisfied with working majorities and not absolute ownership. Alternatively, it may be important to get rid of dissenting shareholders in a small private corporation since they may be a nuisance to the efficient running of the company. ${ }^{32}$ As a viable compromise between these extremes it may be necessary to consider a unified approach to the general question of take-overs. Thus, if a takeover is subject to the security provisions of the various acts it should also be able to benefit from the compulsory acquisition provisions. ${ }^{33}$ If, how-

20 Companies Act, 1929, 18 \& 20 Geo. 5, c. 23, s. 155. This was first adopted in Canada by the Dominion Companies Act, 24.25 Geo. 5, S.C. 1934, c. 33, s. 124.

27 Report of the Company Law Amendment Committee, supra, n. 22.

28 The Quebec Companies Act, supra, n. 21, speaks of "an offer to acquire all the shares". It thus includes the case of an offer other than from a company.

29 In England section 209 itself refers to a corporation "within the meaning of this Act or not" while in Canada a similar position is reached by combining s. 136 with the definition of "any other company" in 8. 3(1). Other statutes take one or other of these approaches. On the other hand, British Columbia defines a company only to include a company incorporated under the British Columbia Act and does not within the section itself refer to outside companies.

30 The original Indian provision only required approval by seventy-five percent of the shareholders as did the former Manitoba section.

31 Thompson, Statutory Expropriation of the Minority Shareholder, (1962-64) 4 Syd. L.R. 87.

33 It was just such a situation which gave rise to the case of Re Bugle Press [1961] 1 Ch. 271 which will be discussed more fully later. (See infra, n. 84.)

33 The security law provisions governing take-overs may be found either in the Company Acts themselves or in separate Security Acts. These security law provisions govern firstly the procedure to be followed in a take-over. The main procedural safeguard is to guarantee equality of treatment of all offeree shareholders while at the same time giving each offeree shareholder sufficient time to make a decision as to whether to accept or reject a take-over offer. Secondly the security law provisions set out what information must be made available to an offeree shareholder to enable the offeree shareholder to decide whether to accept or reject the take-over offer. 
ever, the take-over is an exempt offer under the relevant security legislation it may be that it should not be able to invoke the power of expropriation. ${ }^{34}$

In 1945 the Cohen Committee, ${ }^{35}$ once again, considered the question of the compulsory take-over of the shares of a minority and made two recommendations which are of interest. Firstly, it was recognized that a company already holding more than ten per cent of the shares of another company may wish to make a complete take-over. The committee thus suggested:36

... that it might usefully be extended to cover that case provided that the offer is made to all the holders concerned other than the company itself and is accepted by not less than seventy-five per cent in number of the holders holding between them not less than ninety per cent in value of the shares or class of shares sought to be acquired.

While the writer agrees with this proposal, he submits that it contradicts one of the bases of the Greene Report ${ }^{37}$ which suggested a company would not purchase shares in another company if it could not, from the start, secure a purchase of all the shares. While most jurisdictions have incorporated similar provisions in their respective statutes ${ }^{38}$ neither the Canadian Act nor the acts of any of the other Canadian jurisdictions, with the possible exception of Quebec, ${ }^{39}$ have included such a provision. As will be seen, this has caused some difficulty in Canada.

The second recommendation of interest is that where a company has purchased ninety per cent of the shares of another company, but does not seek to purchase the remainder of the shares, it must notify the minority that it owns ninety per cent of the shares and the minority can then compel the company to purchase its shares. ${ }^{40}$ More significantly, the price to be paid for these shares is either the price paid for the majority shares, a price agreed by the parties, or such other terms as the court may see fit to order. Again, while the merits of this section which is to prevent a minority from being permanently "locked in" as a minority are obvious, it can be seen that it contradicts the view of the Greene Report ${ }^{41}$ that a company would not contemplate a take-over unless it was certain of being able to purchase all the shares. Furthermore, it is rather curious that when a minority demands that its shares be purchased the court is explicitly given control over the price to be paid, but the court has no such control when the minority is forced to sell its shares, where the price to be paid is that under the original take-over offer. The court has a general power to order otherwise but only with respect to the scheme as a whole and not the fixing of the

34 This is not the approach taken by the new Victorian version of the Australian Uniform Companies Act which provides a separate provision for cases governed by the take-over provisions and a separate section for all other cases.

35 Report of the Committee on Company Law Amendment Cmnd. No. 6659, (1945).

36 Id. at 89.

37 Supra, n. 22.

3s Such a provision is found in the United Kingdom, India, South Africa, and New Zealand Acts and in the Australian Uniform Companies Act.

39 See sections 48(5) and 145(5) of the Quebec Companies Act.

40 No court in any jurisdiction under consideration has yet applied this section. However, in Rayfield v. Hands [1960] Ch. 1 the Court allowed the action of a shareholder which required the directors to purchase his shares at a fair price. This right was granted under the articles of association of the company. See a note on the case L.W.M., Compulsory Share Acquisition, (1958) 102 Sol. J. 390 and a note L.C.G.B. The Contractual Effect of Articles of Association, (1958) 21 Mod. L.R. 401.

1 Supra, n. 22. 
share price. While the report itself does not say so, it will be seen that this provision is consistent with the American point of view. Significantly, however, the writer knows of no reported case on this section in any of the jurisdictions under consideration. As with the previous recommendation, although other jurisdictions have included this provision in their acts, neither Canada nor any of the other Canadian jurisdictions have, as yet, done so. ${ }^{42}$

The only similar provision in Canada is section 100 of the Business Corporations Act of Ontario. ${ }^{43}$ It provides that when there has been a fundamental corporate change, such as a disposition of a substantial part of an enterprise, an amendment to the article restricting the transfer of shares, or a resolution or agreement to amalgamate the corporation, then any shareholder voting against the change can demand that his shares be purchased by the corporation. If the parties cannot agree on the price to be paid it shall be determined by the court. This section, however, is limited to private corporations. Under the new Task Force Report ${ }^{44}$ on Company Law a minority will have a right to demand to be bought out at an appraised price. However, this right again would only be given in cases of fundamental corporate change. A court may even appoint one or more appraisers to determine the fair value of the shares. This right is not to be limited to private companies, however, it is unfortunate that the Draft Canada Business Corporations Act has no compulsory acquisition provision. Furthermore the acquisition of ninety percent of the shares of a corporation is not considered a fundamental corporate change.

In 1962 the Jenkins Report 45 once again dealt with the problem of the compulsory acquisition of the shares of a minority and the compulsory acquisition by the company of the shares of a minority shareholder in a take-over situation. Some of the recommendations dealt with technical ambiguities in the section, while others are of substantive importance. ${ }^{46}$ When the United Kingdom Companies Act was amended in 1967 none of the proposals bore any legislative fruit. ${ }^{47}$ The major proposal, as far as concerns the problems at hand, was an attempt to correct the discrepancy, discussed above, which gives a court more power to control the price paid for shares where the minority forces the company to buy its shares, than in the case of the company forcing the minority to sell its shares to the company. It suggested that the court should have this extended power in both cases. It also recommended that in the case where a company already owns more than ten per cent of the shares of the company being acquired, the proviso that three-quarters of the shareholders must approve, should be dropped. More importantly, the Report refused to alter the section to include the case where a take-over is made by an individual rather than a company since it felt the section was enacted to "facilitate the merger of com-

\footnotetext{
12 Similar provisions are included in the acts of the United Kingdom, the States and Territories of Australia, India, The Republic of South Africa, and New Zealand.

4. S.O. 1970, c. 25. See also the Ontario Corporations Act, R.S.O. 1970, c. 89, which may still apply, where the Business Corporations Act does not.

4 See Proposals for a New Business Corporations Law for Canada, Part 14.00 at 114 and Draft Canada Business Corporations Act, s. 14.01.

4s Board of Trade, Report of the Company Law Committee Cmnd. No. 1749 para. 283, at 105 (1962).

46 For a full discussion of the technical ambiguities in the section see Weinberg, Take-Overs and Amalgamations, supra, $n$. 23 at 143 and specifically as regards the ambiguities when a minority forces the company to buy its shares at 158-162.

${ }^{77}$ Companies Act, 1967, c. 81 .
} 
panies". This is a failure to recognize the original intent of the section, which was to prevent the oppression of the majority by the minority. It is true that the original suggestion was made within the framework of company amalgamations, but the reason for setting up committees to look into and revise legislation is not to see the reason for previous changes, but to discover what further changes must be made. Furthermore, oppression exists regardless of whether the take-over is by a company, by an individual, by a group of individuals or by a group of companies. ${ }^{48}$ The fact that the Quebec statute made provision for the situation where an individual is taking over may be due to the fact that it was enacted after the Jenkins Report was made. ${ }^{49}$ Indeed, the converse problem of allowing a minority to require its shares to be purchased in order to prevent it from being locked in a minority position can also arise when it is not a company, but rather a group of companies or an individual that is making the take-over.

\section{What Is a Scheme or Contract?}

On approaching the legislation itself, the first criterion is to see whether there is a scheme or contract within the meaning of the Act. ${ }^{50}$ The Canadian Act speaks only of a contract while the United Kingdom Act uses both these terms. This would give the impression that the term "contract" is the wider concept of the two.51 However, the English Act contains no definition of the terms, ${ }^{52}$ whereas the Canadian Act ${ }^{53}$ defines "contract" rather broadly and indicates that it "includes" a scheme. Moreover, it sets out a number of situations which would give the impression that it is not a limitative definition. A number of obiter dicta, however, have sought to limit the content of the word "contract".

The most narrow approach was that taken by Rand J., as he then was, in Rathie v. Montreal Trust Company ${ }^{54}$ where he says at page 212:55

What, for instance, does the word 'contract', even including 'an offer of exchange and any plan or arrangement' mean? With whom is the contract made? Certainly not with the shareholders; both the singular number and the fact that their individual acceptances would be necessary exclude that; and I doubt that the word

48 In Australia the Interim Report of the Select Committee on Company Law (Eggleston Report) suggested that the section be amended to include the case where an individual buys ninety per cent of the shares of a company. This has been incorporated into the new Victorian version of the Australian Uniform Companies Act, s. 180 and s. 185(1).

19. An Act to Amend the Quebec Companies Act S.Q. 1963, c. 54, s. 1.

so Various legislation uses one or other of these terms.

s7 Moreover, a scheme within the section can itself be part of a larger scheme. See Sammel v. President Brand Gold Mining Co. Led. [1969] 3 S.A. 699. Nor does a scheme, to have all the shares purchased by an outsider, always fall within the section: e.g. Re National Bank, Ltd. [1966] I W.L.R. 819.

52 Re Canadian Food Products Ltd. and Picardy Ltd. [1945] 2 W.W.R. 65 at 71 (Man. C.A.).

s3 S. 136(4)(a).

s4 [1953] 2 S.C.R. 204, reversing [1952] 4 D.L.R. 448 (B.C.C.A.) which had affirmed [1952] 3 D.L.R. 61 (B.C.S.C.)

ss This narrow view was accepted by Laidlaw J.A. in Re International Petroleum Co. Ltd. [1962] O.R. 705 at 714 (C.A.), aff'd. sub. nom. Esso Standard (Inter-America) Inc. v. J. W. Enterprises [1963] S.C.R. 144. However, the point was obiter. In Australian Consolidated Press Ltd. v. Australian Newsprint Mills Holding Led. (1960-61) 105 C.L.R. 473 at 484 (High Court of Australia) Fullager and Menzies JJ. state: "The word 'contract' in 8 . 130B no doubt pre-supposes the agreement of the company which makes an offer with some other persons but not necessarily the company whose shares are to be transferred." This, it is submitted, is the correct interpretation. The section here did have the word "scheme" but as stated the wide definition in the Canadian Act would include both. However, the Privy Council decided in Blue Metal Industries Ltd. v. R. W. Dilley [1969] 3 W.L.R. 357 approving (1966-67) 116 C.L.R. 445 (High Court of Australia) that the offeror or transferee company can only be a single company as this was necessary to properly apply this section. While this case will be dealt with later, it is submitted that to limit the notion of the section in the case where a company makes a general offer to shareholders would prevent the application of the Bection in most cases. 
'exchange' although in one sense including purchase, is an exemplary use of language.

With respect, the learned Justice failed to recognize a number of points. First, as mentioned, the definition of contract is not limitative. Second, the legislative history of the section includes the concept of a scheme. Third, the Interpretation Act" specifies that "words in the singular include the plural and words in the plural include the singular". ${ }^{57}$ The argument, that it would be impossible to find the starting date to apply the section, hardly seems valid as this is a question of fact to be determined by the court. In fact, no case yet reported has dealt with the question of the difficulty of determining the starting date.

The crux of the problem, however, is the opinion of Rand J. that the section applies when the offeror company makes the offer to the offeree company, which in turn would submit it to its shareholders. This, however, would prevent the application of this section in the exact situation where it is most likely to apply today, namely, in the cash tender offer to the shareholders individually either by public advertisements in the newspapers or by individual letters. Furthermore, this method avoids the problem of determining the starting date, as the date of the publication or of the letter can be taken as the starting date. Indeed, the offeree company cannot approve the "contract" of transferring the shares in that they are owned not by the company but by individual shareholders. ${ }^{58}$

\section{Interpretation of the Section by the Courts-Procedural Aspects}

In looking at the cases on this provision in Canada one finds that the courts seem to take a much stricter approach in interpreting the provision than seems to be the case in other jurisdictions. ${ }^{59}$ The courts seem inclined to the view that as regards procedural aspects the wording of the section must be strictly interpreted. In two instances Canadian Courts have held that the offer must be open for the full four months required under the section. ${ }^{60}$ The basis for the decision by the Supreme Court in Rathie ${ }^{61}$ was that the full four months is needed to allow the shareholders to make an adequate investigation as to whether the offer was fair. However, if ninety per cent of the independent shareholders have adequate time to ascertain this information why should not the same hold true for the minority as well? Both the English Chancery Division in Re Western Manufacturing (Reading) Ltd.,62 and the Australian High Court in Australian Consolidated Press Ltd. v.

\footnotetext{
56 Interpretation Act, S.C. 1968-69, c. 7, s. 26(7). The applicable section at the time the case was decided was Interpretation Act, R.S.C. 1927, c. 1 , s. $31(1)(J)$ which is exactly the same in wording.

57 In Re Press Caps Ltd. [1949] 1 Ch. 434. Somervell J. at 443, rejected any notion of singularity in the English section.

so The view of Coady J. at trial, in the Rathie case, [1952] 3 D.L.R. 61 at 65 is on point. He notes that although the section appears under a heading of "arrangements and compromises" the other sections under the heading involve an action in the name of the company whereas the present section related to a sale of shares.

39 For a summary of the Canadian position see Bird, Corporate Mergers and Acquisitions in Canada, (1968) 18 U.N.B.L.J. 16 at 36

60 Rathie v. Montreal Trust Co., supra, n. 54. Here the offer was not open for four months. In Re Waterous and Koehring-Waterous Ltd. [1954] 4 D.L.R. 839 (Ont. C.A.) the original offer was not open for four months although the extended offer was. Yet the Court refused to apply the section.

61 Supra, n. 54.

62 [1956] 1 Ch. 437. In a note on this case, however, the Canadian decision was favoured. See H.N.B. Compulsory Purchase of Dissenters' Shareholdings, (1956) 100 Sol. J. 62.
} 
Australian Newsprint Mills Holding Ltd.63 declined to follow the Canadian approach. Although the Canadian view is commendable in that it tries to assure that adequate information is available in order to judge the fairmess of the offer, this problem could be overcome by requiring that adequate information be included in take-over offers in general.64 The decision, it may be added, is also contrary to the views of the Jenkins Report. ${ }^{65}$ Furthermore, it would cause enormous inconvenience if the delays in companies and securities enactments differ.66 The Canada Corporations Act now includes the regulation of take-overs in general as well as the compulsory acquisition provision. ${ }^{67}$ Some provinces have provided for both, with the regulation of take-overs in the general securities acts and the compulsory take-over provision in the companies acts. Ontario, which was the leader in Canadian security legislation, does not have any compulsory take-over provision. ${ }^{68}$ In Australia relevant provisions are contained in the various companies acts, ${ }^{69}$ but the United Kingdom as yet has no general take-over legislation. ${ }^{70}$ Thus, now that adequate information is, or will be, more readily available, the fear expressed by Locke J. in the Rathie case ${ }^{71}$ is no longer justified and the four months should be interpreted as a maximum period. ${ }^{72}$

The case of Re Canadian Breweries ${ }^{73}$ illustrates the problem which arises in the absence of a statutory provision dealing with the case of a take-over by a company which already owns more than ten per cent of the shares of the company being taken over. Canadian Breweries made an offer to purchase all the shares of Dow Breweries in 1952

${ }^{63}$ (1959-60) 105 C.L.R. 473 (High Court of Australia), approving [1959] Tas. S.R. 167 (Supreme Court of Tasmania). The Scottish Court of Appeal (First Division) in applying the United Kingdom Act did however, take a strict view of extending the time beyond four months by refusing to hold that the extension con. stituted a new offer. See Musson v. Howard Glasgow Associates [1961] S.C. 371.

s4 In any case the shareholders can be guaranteed to receive adequate information by one of two methods. Under s. 136 of the Canada Corporations Act, supra, n. 21, the shareholder must receive notice in such manner as may be prescribed by the court. This, it is submitted, could be used to guarantee adequate information. A second method is for the Act to require notice in a "prescribed manner" and provide for this by regulation. See s. 153 of The Companies Act of Alberta and s. 11 of Reg. 227/67, O.C. 1017/67, s. 2 of Reg. 204/70 O.C. 1103/70 and Form C.R. 12. This was passed pursuant to s. 138 of The Companies Act of Alberta, R.S.A. 1955, c. 53 which is the same as the present 8.153.

es Board of Trade, Report of the Company Law Committee,Cmnd. No. 1749 para. 286 at 106 (1962).

66 This problem is avoided in the proposed New Victorian version of the Australian Uniform Companies Act having ss. $180 \mathrm{X}$ and $180 \mathrm{Y}$ deal specifically with the case covered by the take-over provisions of the legislation and new s. 185 applying in other cases.

67 R.S.C. 1970 , c. C-32, 8. 135-1 et. seq.

so The Ontario Select Committee on Company Law of 1952 rejected the idea of including such a provision in the Ontario legislation but did not state any reason for so doing. See Report of the Special Committee of the Legislature of the Province of Ontario Charged with the Revision of The Companies Act (Ontario) and Related Acts at 10 (printed version) or at 12 (submitted version). An indication as to why such a provision was rejected is found in a memorandum prepared for the Select Committee on Company Law of Ontario of 1967 by Mr. Samuel Lavine, Director of Research. See Re: Right of a Majority of the Shareholders to Buy Out the Minority and Right of a Minority to Require the Majority to Buy Them Out at 78, where Mr. Lavine gives as one reason the dislike at the time for what was felt to be private expropria. tion. A second reason was that at the time the committee was meeting a case involving Canadian Admiral had evoked criticism of the company and of the principle of law involved. Thus the committee recommended against such a provision despite the fact the Second Draft Bill circulated by the committee contained such a provision. The 1967 Interim Report of the Select Committee on Company Law (The Lawrence Report), due no doubt to the memorandum prepared by Mr. Lavine, omitted any mention of such a provision. This omission has been criticized. See Davies, Future Developments in Company Law, 1968 Law Society of Upper Canada Special Lectures, 365 at 374 ('Toronto 1968). See also Mackinnon, The Protection of Dissenting Shareholders in Studies in Canadian Company Law, supra, n. 2 at 507 and 518.

B9 Sections 184 and 185 of the various state acts.

70 There are regulations as regards take-overs by licensed dealers. These are made under the Prevention of Fraud (Investments) Act, 6 \& 7 Eliz. 11, c. 45.

71 [1953] 2 S.C.R. 204.

72 The Jenkins Report, supra, n. 65 at 106 , favoured allowing the transferee company to apply for compulsory acquisition as soon as it had purchased 90 per cent of the shares.

n] [1964] C.S. 600 (Quebec Superior Court) per Collins J. 
and because not enough shareholders accepted the offer, the Act did not apply. Subsequently, Canadian Breweries continued buying shares of Dow on the market until they had accumulated 89 per cent of the shares, after which they made a new offer in 1963 for the remaining shares. The new offer was accepted by 93.4 per cent of the remaining shareholders. On an application by Canadian Breweries to the Court, Collins J. refused to apply the section holding that it only applies to a class of shares and not to a selected group within a class. ${ }^{74}$ It must be observed, with respect, that the learned judge's interpretation of the section did not apply since the offer was made to the remaining shareholders and not to a group of shareholders selected at random. ${ }^{75}$ The effect of the decision would be to prevent a company which initially owns more than ten percent of the shares from ever making use of the section. As has been shown, other Acts provide explicitly for such a situation by having a double qualification for acceptance by ninety per cent in value of the remaining shares as well as three-quarters of the shareholders. In addition, the offer must be made to all the remaining shareholders. Although it may be argued that the Canadian and provincial sections are wide enough to cover such a situation, it must be noted that the United Kingdom amendment was a result of a specific recommendation of the Cohen Report ${ }^{76}$ which indicated that the existing legislation was not applicable in such a situation. Thus, the Canadian and provincial acts should be amended to include such a provision since it is very common for a company to first buy shares on the market to an extent greater than ten per cent and to then make a general tender offer. Furthermore, it is necessary to integrate the concept of takeovers with the provisions found in security legislation since there the question of pre-purchase by a company is dealt with rather carefully, and it would seem contradictory to force a company to give minute details of its pre-purchase and then prevent it from using the compulsory acquisition provisions because it has in fact engaged in a pre-purchase. ${ }^{77}$

The basis of the strictness of the Canadian approach seems to be dictated by a view that the legislation is in fact confiscatory. This was the conclusion of Manson J. in Re John Labatt and Lucky Lager Breweries $L t d .{ }^{78}$ where the compulsory take-over order was refused when it was found that the order and the notice to the dissenting shareholders

74 The Quebec Companies Act, R.S.Q. 1964, s. 48(5) contains a rather interesting provision:

An offer to acquire all the shares of a certain class, except those of a shareholder mentioned therein, shall give rise to the application of this section if it is accepted by the holders of $9 / 10$ of the shares

to which it refers and the offeror acquires, on the same conditions, the shares of the shareholder mentioned.

Note that the exclusion is that of " $a$ " shareholder. The section would seem to be capable of being interpreted in such a way as to apply to the plural as well. Presumably the section is intended to cover the case where a large block of shares is purchased from one shareholder and then an offer is made for the balance. Furthermore, the same price must be paid. It is submitted that the U.K. section is preferable to this limited approach. It may be that the learned judge was confusing these two sections in deciding the case.

75 See a note on the case, Rowley (1967-68) 6 Alta. L. Rev. 117 as well as a note by McCartney (1964) 22 Fac. L.R. 167.

76 Supra, n. 35 at 89. However, in Lewis Emanuel \& Son Ltd. v. Lombard Australia Ltd. and Lombard Banking Ltd. [1963] N.S.W.R. 38 the Court was faced with a similar problem and held that ninety per cent approval meant ninety per cent of the other shares. At the time s. 135 of the New South Wales Act did not specifically cover such a situation. Thus the Quebec court could have decided otherwise despite the caution in the Cohen Report.

${ }^{77}$ Under the various security legislations one is deemed to be an outsider when owning ten per cent of the shares of a company. Thus it is obviously beneficial to own slightly less. This is, however, a deterrent to providing shareholders with more information. It seems undesirable to add a second deterrent by making the compulsory acquisition inapplicable when a company owns ten per cent of the shares of another company.

78 (1959) 29 W.W.R. (N.S.) 323 (B.C.S.C.) per Manson J. 
were wrongly issued under a previously repealed act and not under the replacement section in the new act, although there was in fact no difference between the two sections. However, the Privy Council in Blue Metal Industries v. $R$. W. Dilley ${ }^{79}$ refused to apply the corresponding section partly on the basis that an "involuntary acquisition" 80 section must be strictly interpreted. In future, this may indicate a stricter procedural approach to such sections based on the view that the take-over is an expropriation. ${ }^{81}$ However, the decision here to refuse to allow a joint take-over by two companies has been severely criticized for not taking into account that the result would lead the minority shareholder to remain "locked in" as he also would be unable to force the two companies to buy him out.82 Furthermore, the goal of an integrated and comprehensive legislative approach to this problem would also be hampered by the present decision. Since a number of companies can make a joint offer and be subject to the take-over provisions of security legislation, it seems reasonable to give them also the right to apply the compulsory acquisition provisions. Although the Privy Council indicated it would look unfavourably on the setting up of a new company by the two other companies to overcome this decision, ${ }^{83}$ it cannot be denied that such a decision does encourage the use of "legal dodges".

\section{The Special Case of the Independence of Offeror and Offeree}

The element of procedural strictness which has been most often commented upon has been the requirement of independence between the offeror and offeree companies. The first case in which this problem had to be faced was Re Bugle Press; Re Houses and Estates Ltd. ${ }^{84}$ Here the two principal shareholders of Bugle Press Limited owned 9,000 shares out of the 10,000 shares issued, with the remainder owned by a third shareholder. Desirous of getting rid of the latter, the principal shareholders incorporated a new company, Jackson and Shaw (Holdings) Limited. The new company made an offer to purchase all the shares of Bugle Press Ltd. When the dissenting shareholder refused the offer for his shares he was given notice under section 209 of the United King. dom Act that the company would seek a court order to obtain his shares. The minority shareholder sought a declaration that the new company was neither entitled nor bound to acquire his shares. At Chancery Division, Buckley J. held that the company had not satisfied the onus of proving that the price offered for the shares was fair. ${ }^{85}$ On appeal, the Court of Appeal held that due to the special circumstances of the

79 [1969] 3 W.L.R. 357 approving (1966-67) 116 C.L.R. 445 (High Court of Australia).

so Id. at 366.

81 However, in the recent case of Re Simco Securities Trust Ltd. [1971] 1 W.L.R. 1455 (Chancery Division) the section was interpreted very broadly by holding that approval by shareholders included those who had an absolute right to an allotment of shares.

az See a note on the case (1969) 14 Jurid Rev. (N.S.) 260. The policy consideration of the case are also discussed in R.K. Peterson, Take-Over Bids and Companies Act, (1968-70) 5 V.U.W.L.R. 447 at 454 . In Re Samuel Heap \& Son Ltd. (1965) W.L.R. 1458 (C.A.) the section was procedurally interpreted in favour of the dissenting shareholder where it was a question of whether he had gone to the right Court. See James H. Thompson, Application to Court Under Section 209; Meaning of Court, (1966) J. Bus. L. 256.

3s Blue Metal Industries, supra, n. 79 at 366 . Due to the extended detinition of an offeror this would now be covered by the proposed new Victorian version of the Australian Uniform Companies Act, 8. 180A(2).

84 [1961] 1 Ch. 270 (C.A.). For notes on the case see (1960) 76 L.Q.R. 344; (1961) 77 L.Q.R. 8; Wedderburn, A Corporations Ombudsman? (1960) 23 Mod. L. Rev. 663; R.S. Thompson, Statutory Expropriation of the Minority Shareholder, (1962-64) 4 Syd. L. Rev. 87; and Getz, Unfair Take-Overs, (1961) 78 S.A.L.J. 438. See also Hampton, Compulsory Acquisitions of Shares in Joint Take-Over Offers, (1970) 4 N.Z.U.L. Rev. 168.

ss A second case dealing with Houses and Estates Ltd., was decided at the same time and dealt with sub. stantially the same facts. 
case it would exercise its residual power of ordering otherwise. The Court lifted the corporate veil ${ }^{86}$ and held that the new company, although in law a distinct person, was in substance the original shareholders. Evershed M.R. stated:87 Nevertheless, when regard is had to the opening words and to the parenthesis, it
seems to me plain that what the section is directed to is a case where there is
a scheme or contract for the acquisition of a company, its amalgamation, reorganiza-
tion or the like, and where the offeror is independent of the shareholders in the
transferor company or at least independent of that part or fraction of them from
which the ninety per cent is to be derived. Even, therefore, though the present
case does fall strictly within the terms of section 209 , the fact that the offeror, the
transferee company, is for all practical purposes entirely equivalent to the nine-
tenths of the shareholders who have accepted the offer, makes it in my judgment a
case in which, for the purposes of exercising the court's discretion, the circumstances
are special-a case, therefore, of a kind contemplated by Maugham J. to which his
general rule would not be applicable. It is no doubt true to say that it is still for
the minority shareholder to establish that the discretion should be exercised in the way
he seeks.. But if the minority shareholder does show, as he shows here, that the
offeror and the ninety per cent of the transferor company's shareholders are the
same, then as it seems to me he has, prima facie, shown that the court ought
otherwise to order, since if it should not do so do the result would be, as Mr.
Instone concedes that the section has been used not for the purpose of any scheme
or contract properly so called or contemplated by the section but for the quite
different purpose of enabling majority shareholders to expropriate or evict the
minority; and that, as it seems to me, is something for the purpose of which, prima
facie, the court ought not to allow the section to be invoked-unless at any rate it
were shown that there was some good reason in the interests of the company for so
doing, for example, that the minority shareholder was in some way acting in a manner
destructive or highly damaging to the interests of the company from some motives
entirely his own.

The decision of the Court of Appeal was that it would exercise its power of "ordering otherwise". There was, however, some question as to whether the section had any application at all. This depended on an argument that the fact situation was such that no "scheme or contract" existed within the meaning of the section. The Court below had never heard this argument and at appeal this reasoning suffered from the defect of not having been notified as a ground of appeal, and when finally argued it was only junior counsel who discussed the point. Harman J. would have been prepared to hold that the section did not apply at all if the point had been raised earlier. ${ }^{88}$ Although not important as far as this decision is concerned, it could, in certain situations, be of importance. ${ }^{89}$ Evidence of the lack of independence of the transferee

so See Wedderburn, supra, n. 84. He points out a phony incorporation could not make use of 8.209 if unfairness is caused. However, see Re Dad's Cookie Co. (B.C.) Ltd. (1970) 7 D.L.R. (3d) 243 (B.C.S.C.) where a new incorporation was allowed where there was no unfairness; C.S.M., Amalgamations: Opposition by Dissenting Shareholders Onus of Proof, (1960) J. Bus. L. 350; Samuels, Lifting the Veil, (1964) J. Bus. L. 107 at 108 for a general discussion on the question of lifting the corporate veil, see Pickering, The Company as a Separate Legal Entity, (1968) 31 Mod. L. Rev. 481 and Feltham, Lifting the Corporate Veil in Developments in Company Law, 1968 Law Society of Upper Canada Special Lectures 305 (Toronto 1968).

${ }^{97}$ [1961] Ch. 270 at 286. Note that in Re Julius G. Day and Canadian International Paper Company (1949) 29 C.B.R. 230 the majority tried to use the Canadian s. 128 not in a take-over but to get rid of a minority and the Court said the section could not be used for this purpose. However, in the Indian case of Benarsi Des Saraf v. Dalmia Dadri Cement Lid. (1959) A.I.R. (Punjab) 232 the transferee company was set up to get rid of an unwanted minority. Here the minority actually abandoned their claim that the compulsory acquisition section did not apply and tried instead to prevent registration of the shares in question. Although the Court did not have to decide the question it seems it would have allowed the compulsory acquisition.

58 Id. at 288 .

69 This was pointed out in a note discussing the Esso Standard case, supra, n. 55 by McCartney (1964) 22 Fac. L.R. 167. If the section applies but the Court orders otherwise the company is bound and en. titled to acquire the shares of a dissenting shareholder who did not move for an order. If the section does not apply the company is not entitled to acquire the shares held by any of the dissenting shareholders. 
and the majority shareholders of the transferor company is a prima facie ground to "order otherwise", since the section is then being used to expropriate the minority at the expense of the majority. In spite of this, the Court still would have allowed the section to apply for "some good reason in the interests of the company". Thus, here we have the criterion, in both its formulations which was applied at common $\mathrm{law}^{90}$ to expropriate the shares of a minority shareholder. Despite the "scheme" devised here, the Court would still have been prepared to sanction the take-over, if it had been in the interest of the company, but refused to allow it as a device which discriminated between the majority and minority shareholders. Thus the expropriation or compulsory acquisition can only be used in a genuine take-over; if it is in fact a device to get rid of a minority, the same test applies both under the compulsory acquisition section and at common law.

This decision was followed by the Supreme Court of Canada in the case of Esso Standard (Inter-America) Inc. v. J. W. Enterprises. ${ }^{91}$ In this case Esso Standard, the transferee company (offeror) made an offer to purchase all the outstanding shares of International Petroleum Company Ltd. (International), the offeree company. Ninety-six per cent of the shares of International were owned by Standard Oil Company. It also owned all the shares of Esso Standard and readily accepted the offer of Esso Standard for its shares in International. The Court applied the principle laid down in Re Bugle. ${ }^{92}$. Judson J. held that:93

\begin{abstract}
[t]here is no distinction between Bugle Press and the present case either on fact or law. This was the opinion of Laidlaw J.A. and I fully agree. We have here 90 per cent ownership in Standard Oil Company (New Jersey). The promoting force throughout is obviously that of Standard Oil and not its subsidiary. A transfer of shares from Standard Oil to Esso Standard is meaningless in these circumstances as affording any indication of a transaction which the court ought to approve as representing the wishes of 90 per cent of the shareholders. This 90 per cent is not independent. On this ground alone I would reject the appeal and hold that the section contem. plates the acquisition of 90 per cent of the total issued shares of the class affected and that this 90 per cent must be independently held.
\end{abstract}

While one could disagree with the Supreme Court and distinguish $R e$ Bugle either on the basis that, there, the transferee company was always in existence or on the basis that the corporation involved is not a small private corporation but is a large public corporation, it can be seen that the real ratio of the Esso case was that the compulsory acquisition section cannot be used to expropriate the shares of an unwilling minority. The Canadian Court has adopted the view that it may allow the section to be used if some valid purpose in the interest of the company is served by so doing. However, the Court, when giving supplementary reasons, held that the section did not apply at all,99 thus, the Canadian law may still not be settled on this point.

What the Canadian case did do, however, was to emphasize a criterion which may be of use when dealing with such a situation in the future. In the view of the Court the transferee must be independent ${ }^{95}$ from the

\footnotetext{
so Strictly speaking, the expropriation cases only spoke in terms of "bona fide in the interests of the company as a whole" but Greenhalgh v. Arderne Cinemas [1951] Ch. 286 (C.A.) equated the two.

91 Supra, n. 55.

92 Supra, n. 84.

93 Supra, n. 55 at 151 .

94 See McCartney, supra, n. 88.

os The Jenkins Report, supra, n. 44 at 107 also spoke in terms of approval by shareholders who are genuinely independent.
} 
majority of the transferor company. ${ }^{96}$ This independence, it now seems, does not have to be absolute and total but is rather a question of degree. In Re Dad's Cookie Co. (B.C.) Ltd. ${ }^{97}$ the Court, in dealing with the similar British Columbia section, allowed the section to apply despite the fact the transferee company was a new company specially set up for the purpose by a shareholder who had a two per cent interest in the transferor company.

The most recent case in which such a problem had to be faced is the South African case of Sammel and Others v. President Brand Gold Mining Co. $L t d .{ }^{98}$ which dealt with similar provision in the South African Act.99 The case limits the criterion of independence to that of original independence. In this case the offeree company Saaiplass had suffered considerable losses and had an accumulated assessed tax loss of R33,000,000. Further, an outstanding loan of $R 10,000,000$ was due, and if liquidated, the proceeds would not cover the debt. The respondent, Brand, could use the Saaiplass ore reduction plant, as well as recover some of the assessed tax loss. ${ }^{100}$ Thus the following scheme was devised and a contract was entered into between Brand, Saaiplass and the latter's creditors. First, the issued share capital of Saaiplass would be reduced by ninety per cent by writing down each share from $R 1$ to ten cents. The reduced shares were then consolidated into $\mathrm{R} 1$ shares leaving the number of shares outstanding at ten per cent of the original number. The reconstructed issued capital would be increased by the creation of more than seven million $\mathrm{R} 1$ shares to be issued to the loan creditors in satisfaction of their debt. Brand agreed to purchase all the issued new R1 shares at sixty cents a share. After settlement of certain outstanding notes this would give the loan creditors fifty-three cents on the Rand. The whole offer was conditional on being accepted by ninety per cent of the shareholders so that section 103ter. of the Companies Act could apply. This plan required special resolutions which could only be passed by a majority of seventy-five per cent of the shareholders. Once approved, the loan creditors who had bound themselves to the scheme would hold ninety per cent of the issued shares so as to make it certain that the Act could apply unless the Court ordered otherwise.

At the trial level the Court refused to hold that the loan creditors were nominees of Brand. On appeal the Court rejected the view that the transferee must be wholly independent or disinterested. This fact cannot be ignored but it is merely a "factor" to be taken into consideration by the Court. Originally the loan creditors and Brand were independent parties. The loan creditors only became shareholders under the reconstruction scheme. Such a situation indicates that the limits of

\footnotetext{
96 Although the English Act has a statement in parentheses excluding shares held by a nominee for the transferee company the Court in Re Bugle held that this provision was not applicable in the situation. The Canadian section does not have such a proviso. Although Judson $J$. found this to be "A significant difference" between the two acts it does not seem to have affected the Courts' decision in Esso Standard since they relied on $R e$ Bugle which did not depend on this proviso. See also the appeal decision of $R e$ International Petroleum [1962] O.R. 705 at 718 per Laidlaw J.

${ }^{77}$ (1970) 7 D.L.R. (3d) 243 (B.C.S.C.). It is also interesting to note that here the transferee company was specifically created to facilitate a take-over. This may be a method of avoiding the requirement that only a company and not an individual can apply the section. However, one must bear in mind warning of the Privy Council in Blue Metal Industries v. Dilley, supra, n. 79 which has already been referred to.

97 [1969] 3 S.A. 629 (App. Div.) affirming [1969] 3 S.A. 699.

9 S. 103 ter.

100 In Government Telephones Board Ltd. v. Hormusji Manekji Seervai (1943) Ind. L.R. (Bombay Series) 581 it was held that there was nothing wrong in deriving a tax benefit.
} 
the "degree of independence" problem will require further judicial consideration to determine its bounds. ${ }^{101}$

The case has another rather unique aspect in that it involves both a reconstruction scheme and a take-over. The former, as has been shown, had always been interpreted by the courts to depend on whether the scheme was made up "bona fide in the interests of the company as a whole". In the latter situation the Court in Re Bugle $e^{102}$ held that this test also applies to compulsory acquisition situations. In the Sammel case the Court was faced with both problems and it applied the same test to both situations. The conjunction of these two problems can be seen in a statement by Trollip J. A.: ${ }^{103}$

Of course, if the majority of shareholders of a transferor company did force through a reorganization of its share capital not bona fide for the benefit of the company as a whole, but solely to benefit themselves or the transferee company at the expense of the minority shareholders by thereby watering down their voting strength to below 10 per cent and thus enabling the transferee company to expropriate their shares under sec. 103 ter. the position might well be entirely different.

The Court thus held that here the scheme was bona fide in the interests of the company as a whole and not merely a device to expropriate the minority shareholders. ${ }^{104}$ Although one may quarrel with this view it must be noted that the shareholders did not oppose the reconstruction aspect of the scheme. What they did object to was their being forced to sell their shares and not benefit from the reconstruction. In fact, the Court extended the test of fairness to include not only fairness to the shareholders but to the creditors as well. If the company had been wound up the creditors would have suffered, but the shareholders would have received nothing, whereas in fact both the creditors and the shareholders benefited. One can only wonder how far other courts will go in considering benefits to creditors in future cases.

\section{Interpretation of the Section by the Courts-Appraisal Aspects}

It is in the second type of case, where a court is asked to "order otherwise" because the offer was thought to be unfair, that the performance of the courts has been most disappointing. When originally enacted, the section contained a proviso which dealt in particular with cases which had involved a take-over prior to the enactment. Under the section, as it read originally, the terms on which the shares of the dissenting shareholders were to be acquired would be such terms as the Court might order, instead of the terms provided by the scheme or contract. ${ }^{105}$

In the first reported case on the subject of compulsory acquisition, Re Castner-Keller Alkali Co. Ltd., ${ }^{106}$ Eve J. did, in fact, vary the terms

103 Suppose the Re Bugle situation where two shareholders who together hold ninety per cent of the shares of a company want to get rid of a third owning the remaining ten per cent. They find a company which is on the verge of bankrupcy and enter into an agreement with it whereby they agree to purchase all its shares if the company makes an offer to purchase all the shares of the company of which they hold ninety per cent. They also agree to loan the company the money to purchase the dissenters' shares. Will a court accept an application of the company to apply the compulsory acquisition provisions or will the court reject it on the ground of lack of independence? Also, the other shares are not held by a nominee for the transferee company but the transferee company may be a nominee for the majority shareholder.

102 Supra, n. 84.

${ }^{103}$ [1969] 3 S.A. 629 at 687 .

104 See a note on the case R. C. Beuthen, Take-Overs Section 103 ter., (1970) 87 S.A.L.J. 276 at 280. For other notes on the case see J. S. McLennon, Take-Over Bids and the Court's Discretion, (1969) 86 S.A.L.J. at 401 and H. Rajak, Minority Rights and the Take-Over Bid, (1970) 87 S.A.L.J. 12.

105 Companies Act, 1928, 18 \& 19 Geo. 5, c. 45, 8. 50, Companies Act, 1929, 19 \& 20 Geo. 5, c. 23, s. 155.

106 (1930) 2 Ch. 349. 
of the take-over. What is even more surprising is that the action was not taken by a dissenting shareholder but by the company seeking the order for compulsory acquisition. One may indeed wonder why the legislation limited the right of the court to consider the terms of the offer to cases arising before the commencement of the Act.107 Furthermore, the fact that the section appeared originally to allow a variation in one special instance would preclude the Court from acting in other situations.

The first case to deal solely with the question of whether or not to approve a scheme was $R e$ Hoare and Company Limited, ${ }^{108}$ a case which has set the tone for all subsequent decisions. Here Maugham J. held that once an offer has been accepted by ninety per cent of the shareholders it must prima facie be taken as being a fair offer and the burden is shifted to those who dissent to show why it should not be accepted. In his Lordship's words: 109

The other conclusion I draw is this, that again prima facie the court ought to regard the scheme as a fair one inasmuch as it seems to me impossible to suppose that the court, in the absence of very strong grounds, is to be entitled to set up its own view of the fairness of the scheme in opposition to so very large a majority of the shareholders who are concerned. Accordingly, without expressing a final opinion on the matter, because there may be special circumstances in special cases, I am unable to see that I have any right to order otherwise in such a case as I have before me, unless it is affirmatively established that, notwithstanding the views of a very large majority of shareholders the scheme is unfair.

The learned judge also felt that the fact that the sale of the shares was compulsory was not a factor to be considered by the Court.

The first reported case to follow this decision was the Indian case of Government Telephone Board v. Hormusji Manekji Seervai. ${ }^{110}$ Here it was made quite clear that a Court must accept the view of the majority unless they based their decision on misrepresented information. It is not sufficient to show that a wrong principle was used as the basis of the valuation. The Court strongly pointed out that the only alternative was to "order otherwise", but it could not revise the terms of the offer. All subsequent cases where the Court must decide the question of valuation have been decided on the same basis.111 Perhaps the most illustrative statement on this question is that by Vaisey J. in Re Sussex Brick Co. Ltd. where the learned judge says: 112

\footnotetext{
107 In the case of Government Telephones Board Ltd. v. Hormusji Manekji Seervai, supra, n. 100 at 593 this point was also discussed.

108 (1934) 150 L.T. 374 (Ch.D.)

109 Id.

110 Supra, n. 100. The case arose out of an expropriation by the Indian Government. Instead of expropriating the property as it could have done, the government set up a company to take over the other companies by acquiring their shares. It is interesting to note that the Indian Companies Act at the time required acceptance by only three-quarters of the shareholders in order for the compulsory acquisition provisions (Section 153B of the Companies Act) to apply.

11 Re Evertite Locknuts Limited [1945] 1 Ch. 220; Re Press Caps Ltd. [1949] 1 Ch. 435 (C.A.); Re Trinidad Oil Co. Ltd., The Times, April 13, 1957, at 3; Re Sussex Brick Co. Ltd. [1961] 1 Ch. 289; Nidditch v. Calcio Printers' Ass. [1961] S.L.T. 282; Re Fras. Hinde \& Sons Ltd. The Times, April 23, 1966, at 8; Re Claridge Holt \& Co., The Times, November 23, 1966, at 8; Re Grierson, Oldham \& Adam Ltd. [1968] Ch. 17; Re Shopper City Ltd. and M. Loeb Ltd. [1969] 1 O.R. 449; Leela Makajan v. T. Stanes \& Co. Ltd. (1957) 2 A.I.R. (Madras Series) 225; Mia v. Anglo.Cement Ltd. (1970) S.A. 281; Re Marston Valley Brick Co. Ltd. (1971) 115 S.J. 10; and Re Carlton Holdings Ltd. [1971] 1 W.L.R. 918. See also C.M.S., Minority Shareholders Challenge of Take-Over Bid, (1957) J. Bus. L. 292; Comment on Re Trinidad Oil, Thompson, Take-Over Bids: Compulsory Acquisitions of Dissentients (1967) J. Bus. L. 229 (Note on Re Grierson, Oldham and Adams); and Leigh, The Awkward Squad (1967) 30 Mod. L. rev. 576 (Note on Re Grierson, Oldham and Adams). For a discussion of the cases see Baxt, The Unprotected Shareholder and the Company Acquisition of Shares (1970) J. Bus. L. 86. See Ridge Nominess Ltd. v. Inland Revenue Commissioners [1962] 1 Ch. 376 noted in (1961) J. Bus. L. 291 (C.M.S.) and (1962) J. Bus. L. 66 (C.M.S.). This was followed by Sun Alliance Insurance Ltd. v. Inland Revenue Commissioners (1971) 115 S.J. 32.

112 [1961] 1 Ch. 289 at 291.
} 
I think that the applicant is faced with the very difficult task of discharging an onus which is undoubtedly the heavy one of showing that he, being the only man in the regiment out of step, is the only man whose views ought to prevail.

In Re Bugle Press Ltd.,113 Buckley J., at Chancery Division, was willing to shift the burden of proof to the transferee company to show that the valuation is fair once the dissenting shareholders have proved prima facie that it was not. At appeal, however, the Court was not willing to decide this question.

\section{Problems with the Valuation of Shares}

Akin to the question of value is the method of valuation. It seems that since the courts are willing to hold that an offer which has been accepted by ninety per cent of the shareholders is prima facie fair, then the offer itself is the basic method of evaluation. Courts are thus bowing to the wisdom of businessmen. The courts consider themselves unable to value shares, although this is not the only type of case where a court may be called upon to value shares. An example is the question of share valuation for estate tax purposes. ${ }^{114}$ The market value of the shares may give some indication of their value but the market value may be undervalued due to a conservative dividend policy. Also, as is usually the case in take-over offers, the price offered is somewhat higher than the market price since otherwise the shares would not be tendered.115 A hopeful sign is found in the recent case of Re Dad's Cookie Co. (B.C.) Ltd., ${ }^{116}$ where, although the Court agreed with the offer price which had been accepted by the majority, it did at least deal with the question of expert evidence.

A problem which has occurred in many of the cases and which makes it difficult for a shareholder to determine whether an offer is fair or not is the inadequate furnishing of information. Even the balance sheet, which in many cases is no more than a history of the company's finances, is not in all cases adequate. However, this problem will, to a large extent, disappear with the enactment of security laws which demand more information in the case of tender offers in general. Indeed, this power of acquiring the shares of a minority shareholder is just a special case of the more general problem of tender offers. One of the basic requirements of this new securities legislation, as has been mentioned, is the furnishing of adequate information in tender offers. Once the Securities or Companies. Act require adequate disclosure there will

\footnotetext{
113 Supra, n. 84

114 For example in Dean v. Prince [1954] Ch. 409 (C.A.) neversing [1953] Ch. 590 the value of the shares of a deceased shareholder had to be determined. In Short v. Treasury Commissioners [1948] A.C. 534 (H.L) shares which were seized under the Defence (General) Regulations 1939 had to be valued. The case of the Commissioner of Taxes for the State of Tasmania v. The Perpetual Trustee Executors and Agency Co. of Tasmania Ltd. (1968-69) C.L.R. 325 (H.C.) also had to evaluate shares for estate tax purposes. See also Ovens, The Valuation of Private Companies and Other Properties for Succession Duties and Similar Proposes, (1953-58) 2 U.B.C. Legal Notes 61. Although the article deals with private companies, shares in public companies may be similarly evaluated. Evaluation may also be required in buy-sell agreements between shareholders. See Sohmer, The Buy.Out Provision in Agreements Between Shareholders of Closely Held Companies: Determining the Price, (1970) $30 \mathrm{R}$ du B 308. The recent case of Hinchcliffe (Inspector of Taxes) v. Crabtree [1970] 1 All E.R. 1239 had to evaluate shares for capital gains tax purposes where shares were sold as a result of a take-over. See also Jones (M) v. Jones (R.R.) [1971] 1 W.L.R. 840 where shares had to be evaluated on a petition to wind up; Re Harris \& Sheldon Group Ltd. [1971] 1 W.L.R. 899 where shares had to be revalued on a reduction of capital complicated by decimalization; and Lynall v. I.R.C. [1971] 3 W.L.R. 759 (H.L.) where the value of shares had to be determined for estate duty purposes.

11 In Re Press Caps Ltd. [1949] 1 Ch. 434 (A.C.) the price offered was twenty-five per cent above market. The price offered, however, may be less than the price at which the shares once sold. See Grierson, Oldham \& Adams [1969] Ch. 17.

116 Supra, n. 97.
} 
be no problem with respect to information in the area of compulsory take-overs. The duality of these two types of legislation was recognized in Colortone Holdings Ltd. v. Calsil Ltd. ${ }^{117}$ It noted that by requiring more information in a take-over the problem of lack of knowledge on the part of a dissenting shareholder will be removed. The problem will remain, however, in those cases which are exempt from the takeover provisions.

It is submitted that the ownership of a share comprises two things, the title, which consists of the proprietary aspect of ownership and the economic value of ownership itself. In most cases, the shareholder is more interested in protecting the latter, while the courts have been interested only in protecting the former, and then only in rare instances. A novel approach is that found in the Ghanian Companies Code ${ }^{118}$ which can, in a sense, be considered a model Act. Under section 234(5) the court can refer the compulsory acquisition to the Registrar "who shall appoint one or more competent reporters to investigate the fairness of the offer and to report thereon". A similar provision applies when the shareholders demand that their shares be purchased, although this situation arises when the transferee has acquired three-fourths of the shares and not ninety per cent as under the English Act.119 Thus, when a shareholder demands that his shares be purchased an English court can vary the terms of an offer. The Ghanian solution, however, applies either when a company or a shareholder demands that their shares be purchased and makes use of experts who may be best suited to fix the correct value. ${ }^{120}$

\section{Conclusion}

It has been seen that to a large extent the Canadian courts have been much stricter in applying the section than other courts, although the Privy Council has indicated it may take a stricter view in future. However, once the courts determine that the section does apply the dissenting shareholders can only get the court to order otherwise if the scheme is not bona fide in the interests of the company as a whole, which has come to mean that the section cannot be a guise to expropriate the shares of an unwilling minority. This, as has been shown, is the same test applied by the common law cases which dealt with the question of whether a minority could be forced to sell their shares. It is also necessary to recognize the inter-relationship between take-

113 [1965] V.R. 129 at 131-132 per Gillard J.

11 Act No. 179 of 1963, sections 234 and 235. The code was specially drafted for Ghana by Professor Gower, See The Final Report of Enquiry Into the Working and Administration of the Present Company Law of Ghana (1961) at 176-177. However, the Ghana section gives the dissenting minority shareholder the right to demand shares in the transferee company thus making the transaction, according to the report, a genuine merger when shares are accepted in lieu of cash. For a note on the preparation of the code see Pennington, Company Law In Ghana, (1961) 105 S.J. 717 at 735 and a noie O.K.F., Final Report of the Commission of Enquiry into the Working and Administration of the Present Company Law of Ghana, (1962) 25 Mod. L. Rev. 78.

119 S. 235 (3)

120 A similar suggestion to set up a Corporate Commissioner was made by Professor Wedderburn in a note on Re Bugle. See Wedderburn, $A$ Corporations Ombudsman? supra, $n$. 84. In any case, this is a far cry from the English position where even discovery was refused in Re Press Caps Ltd. [1948] 2 All E.R. 638; Chagla J. granted discovery in Government Telephone Board v. Hormuji Manekji Seervai, supra, n. 100, but this was criticized on appeal. The Australian Uniform Companies Act, s. 185, also contains a rather interesting and possibly useful provision. It allows a dissenting shareholder to demand the names and addresses of all other dissenting shareholders. Thus while an individual shareholder may not be able to afford an action or be able to convince the court of justice of the cause, a number of such shareholders acting together may have a greater chance of success. See Shtein, Some Aspects of Company Take-Overs in Australia, (1965) 5 U. Queens L.J. 47. 
overs in general and the special case of requiring a dissenting minority to sell their shares. It is submitted that legislation dealing with both these questions must be formulated in such a way as to be complementary, as is proposed for Victoria, rather than to conflict. Finally, it must be noted that in no reported case has a shareholder succeeded on the basis of unfair valuation. Even in the case of evidence that the compensation is not entirely adequate the Court is hesitant to change an offer which has been accepted by ninety per cent of the shareholders.

This, it is submitted, is an area where it will be useful to consider the possibilities for change. Ghana has already provided an interesting solution. A start has been made with the provision in the Ontario Business Corporations Act and the proposal by the Canadian Task Force Report that in cases of fundamental corporate change the dissenting shareholders be given a right of appraisal, including in the latter case the appointment by the court of experts to carry out the appraisal. Unfortunately, the Task Force Report also would do away with the compulsory acquisition provision itself. This, it is submitted, is a serious error on the part of the Task Force. After the American law has been dealt with, this question will again be referred to in order to see why this provision should be retained and how, by combining the best features of each system, the best solution may be devised.

\section{THE POSITION IN AMERICAN LAW}

\section{Introduction}

Although American law does not prevent the elimination of minority stockholders, the approach differs notably from that already discussed under the Anglo-Canadian law. The various corporation acts with the possible exception of New Jersey in the United States have no equivalent provisions to the statutory "expropriation" method. This was pointed out in a memorandum to the Jenkins Committee: 121

We do not have anything comparable to the convenient provision in the English law where if one company acquires 90 per cent of the stock of another it may with court approval, force the remaining minority stockholders to sell their shares to the acquiring company at the same price as was paid to the majority stockholders.

It is interesting to note that this provision is referred to as being "convenient". The alternative available to American corporations will be discussed to see whether any of the American provisions can usefully be adopted and adapted by the Anglo-Canadian company law.

121 Memorandum by Davis, Polk, Wardwell, Sunderland and Krendl prepared for the Jenkins Committee and found in Minutes of Evidence taken before the Company Law Committee, vol. 2 at 1070. See also Gower, Some Contrasts Between British and American Corporation Law, (1955-56) 69 Harv. L. Rev. 1369 at 1396. It is interesting to note that while this memorandum refers to the English method as convenient, Professor Gower in the Final Report of the Commission of Enquiry into The Working and Administration of the Present Company Law of Ghana (1961) states at 110 that the reason he has limited the Ghanian position is because: "It is this power to buy shareholders out which makes American investors so critical of the English section." It is submitted that the memorandum view is correct since the largest investors are corporations which prefer to have the right to buy out minority shareholders for cash and which do not hesitate to use the section. See for example Re Trinidad Oil Co. Ltd. The situation in this case was even debated in the English House of Commons and approved by the Chancellor of the Exchequer. See Parliamentary Debates, House of Commons for June $20(1955-56)$ Vol. 554 at 1432-1508 (fifth series). New Jersey, however, has recently introduced a similar provision. See Rosenfeld. Corporate Acquisitions, 1972 Law Society of Upper Canada Special Lectures 367 at 386 and Kippand Wallum, Acquisitions and Attendant Shareholder Rights, (1968-69) 23 Rut. L.R. 723 at 725. 


\section{Alteration of the Corporate Charter}

Under the Anglo-Canadian law it was seen that a number of cases allowed for the alteration of the articles of association in such a way as to eliminate the minority shareholder. It is unlikely, however, that this would be possible under American law. ${ }^{122}$ This has been stated by Professor Dodd: ${ }^{123}$

The purpose of the amending power, is however, to enable the original enterprise to be modified in ways which may seem necessary either to protect the outside public or to enable the enterprise to function in a manner which the majority of the investors therein regard as more efficient. Its purpose is not to enable the property rights of the corporation to be swept away nor to permit the enterprise to be transformed so radically as to bring about, not a mere modification of its original scheme and purpose, but the substitution of something essentially different.

However, there are other ways of achieving the same purpose. Some of these could possibly be used under Anglo-Canadian law while others could not.124 These methods are usually referred to as "squeezing out" or "freezing out" the minority stockholder.

The limitation on the power to alter a corporate charter depends to a large extent on the contractual nature of the charter and the constitutional limitation on the right to alter the charter. Even if the alteration is done by the majority stockholders it is done under a right granted by the state. In fact, there are two contracts under consideration. First, there is a contract between the state and the corporation $^{125}$ and, second, a contract amongst the stockholders themselves. The modern view, however, is that the relationship between the state and the corporation is one of regulation by the state rather than a contractual relationship, with the constitutional limitation being invoked only in extreme cases where "vested rights" are interfered with. However, when minority rights are interfered with, the approach to the problem is to see if the amendment "is necessary to enable the corporation to make adjustments essential to its continued existence". ${ }^{126}$ This, although stated in different words, is the guiding concept of Anglo-Canadian law, namely, "bona fide for the benefit of the company as a whole".

\section{Elimination of Minority Shareholders by Share Redemption}

One method which has succeeded in eliminating a minority shareholder is to require the redemption of his shares. Although it is quite common to have preferred shares which are callable or redeemable in

122 On the power of amendment of corporate charters in general see Henn, Law of Corporations and Other Business Enterprises, St. Paul, 1961, at 539. In the case of Adams v. Protective Union Co. (1911) 96 N.E. 74 the by-law of a company had been amended 80 that if a shareholder died or left the city, the directors could purchase his stock. If the stockholder refused he would receive only one more divided payment. Since other stockholders had also left the city without losing their dividend, the stockholder won his action on the basis of unfair application of the by-law, the court assuming, without deciding, that such an amendment requiring the compulsory sale of shares was valid.

123 Dodd, Dissenting Stockholders and Amendments to Corporate Charters, (1926-7) 75 U. of Pa. L. Rev. 585, 723 at 746. The writer also says at 731: "Nor could the majority pass an amendment which would have the effect of depriving the stockholders of their interest in the corporation".

124 The proposals of the Canadian Task Force Report on company law would have the effect of limiting such activities under Candian federal legislation.

125 Trustees of Dartmouth College v. Woodward (1819) 17 U.S. (4 Wheat) 518 (U.S.S.C.). See Lattin, A Primer on Fundamental Corporate Changes, [1949] 1 W.R.L.R. 3 and Cheros, Amending the Articles of Incorporation, (1962-63) 15 So. Car. L.R. 506.

128 Note, Limitation on Alteration of Shareholders' Rights By Charter Amendment, (1955-56) 69 Harv. L. Rev. 538 at 543 . 
Anglo-Canadian law, ${ }^{127}$ this provision is quite restrictive and does not extend to common shares. ${ }^{28}$ While a similar situation exists in some of the United States, other states provide for the issuance of various classes of stock whose restrictions and qualifications depend on the corporate charter and articles of association. ${ }^{129}$ In such a situation where nothing is said as regards the redemption some states interpret it so as to permit the redemption of stock whereas others hold it to mean that the redemption of common stock is prohibited. ${ }^{130}$

In Lewis v. H. P. Hood \& Sons, In., ${ }^{131}$ the Supreme Judicial Court of Massachusetts was faced with such a situation. The Massachusetts Act does not provide specifically for the case of redemption. A stockholder in a closely-held corporation was asked to redeem his stock, which was possible under an amendment to the charter which provided that the stock could be called at any time. The plaintiff shareholder, who was also an employee of the company, had not followed the company practice of selling his shares on retirement to the corporation or to active directors. The decision of the Court was to uphold the redemption. There was no question as to the validity of the right to recall stock but only as to whether this right was exercised "oppressively or for the purpose of discriminating against a single stockholder or group of stockholders".132 Here the Court held the power was exercised in good faith.

This formulation of a test as to the validity of the charter amendment is similar to the alternate test in Anglo-Canadian law of allowing an amendment so long as it did not discriminate between majority and minority shareholders. ${ }^{133}$ If one considers the positively stated test of Anglo-Canadian law, namely, an alteration is valid if "bona fide and for the benefit of the company as a whole", nothing in the facts of the case show that the power was indeed exercised in such a manner. Furthermore, nothing indicates the Court intended to restrict its decision to such cases. The result here is quite startling if one compares it with the Brown ${ }^{134}$ and Dafen Tinplate ${ }^{135}$ cases. In the former, a two per cent minority could not be forced to sell their shares even if this was a condition precedent for the majority to loan money to the company. In the latter a general power compelling

127 The original position under Trevor v. Whitworth (1887) 12 App. Cas. 409 (H.L.) was that a company could not purchase its own shares. It was only by exception that statutes allowed a company to purchase or redeem its preferred shares. For the American law in general as regards purchase by a corporation of its shares see Israels, Limitation on the Corporate Purchase of its Own Shares, (1968) 22 Sw. L.J. 755 and Dodd, Purchase and Redemption by a Corporation of Its Own Shares: The Substantive Law, (1940-41) 89 U. of Pa. L. Rev. 697.

128 See Canada Corporations Act, R.S.C. 1970, c. C-32, 8. 61 et seq. as amended, s. 60 et seq. Levy, Purchase by an English Company of its Own Shares, (1930-31) 79 U. of Pa. L. Rev. 45.

129 See O'Neal and Derwin, Expulsion or Oppression of Business Associates ("Squeeze-Outs in Small Enterprises"), Durham, N.C. 1961 at 63.

130 Note, Unqualified Redemption of Common Stock-A Question of Public Policy, (1955) 50 Nw. U.L.Rev. 558. Of course there is no problem with such statutes in the case of redeemable preferred stock. See Crimmin \& Peirce Co. v. Kidder Peabody Acceptance Corporation (1933) 185 N.E. 383.

131 (1954) 121 N.E. (2d) 850. See a note on the case in (1954-55) 103 U. of Pa. L.Rev. 819 where the importance of good faith is emphasized. See also Wilder, Compulsory Redemption of Common Stock Allowed, (1954) U. IIl. L.F. 688 and a comment by Simpson, (1955) 35 B.U.L.Rev, 190. The latter note states you must act for the benefit of the corporation and not discriminate between shareholders. But see Breslav v. New York \& Queens Electric Light \& Power Co. (1936) 291 N.Y.S. 932 which prohibited the changing of previously non-callable preferred stock into callable preferred stock.

132 Id. at 583.

133 See Greenhalgh v. Arderne Cinemas, supra, n. 5.

134 Supra, n. 9.

13s Supra, n. 14. 
shareholders to sell their shares was refused. In the present case the Court did not even discuss the generality of the power in the amended articles. ${ }^{136}$

This, however, does not indicate the position taken in all American cases or by all courts. In the earlier case of Greene v. G. H. Rollins $\&$ Sons, ${ }^{137}$ the court was faced with a situation where the plaintiff was contesting the rights of the company to require him to sell his shares in the company. Here, as in the Lewis case, ${ }^{138}$ the plaintiff was a former employee of the company. The court prevented the acquisition of his shares, but even more interesting is the language used by the Chancellor in his judgment. He felt that in this case there was nothing to indicate that, ${ }^{139}$ "the restraint is reasonably necessary to advance the corporation's welfare and promote business success". This is very close to the positive statement of the Anglo-Canadian position. The learned Chancellor went on to point out that the power of redemption is 140 "highly questionable if its avowed purpose is to get rid of certain stockholders of a given class solely because their presence in the stockholding group was undesirable to the rest". This again is rather similar to the approach taken by Anglo-Canadian cases where the courts refused to allow the articles of association to be altered for the sole purpose of expropriating the shares of a minority shareholder. The distinction between the two cases discussed, however, is that in one the court found good faith and in the other it did not. For the present purposes, it suffices to remember that the requirements in the Greene ${ }^{140}$ case are stated in terms similar to the Anglo-Canadian view of the law.

Although the wording is somewhat similar it is submitted that the formulation of the criterion, in Anglo-Canadian law is preferable. This is because the latter test uses the term "bona fide" along with the requirement of benefit to the company as a whole. It is submitted that this formulation is more meaningful as regards the protection of a minority stockholder. Each criterion by itself may not protect such a stockholder. Evidence of this is found in the Lewis ${ }^{142}$ case where, although there was good faith, there was no indication of benefit to the company. ${ }^{143}$

136 It is interesting to note that The Business Corporations Act, S.O. 1970, c. 25, deals separately with the redemption of "special" shares and the purchase of common shares. In the latter case the shares may be purchased but only out of surplus funds. The company cannot however force a shareholder to sell his common shares. See s. 34. By s. 39(5)(b) the company can purchase the shares from former employees but cannot force them to sell the shares. This change in the law comes about due to the recommendation contained in the Lawrence Report. See Interim. Report of the Select Committee on Company Law (Ontario 1967) 34-38. This state differs from the two classes of statutes discussed above in that it specifically provides for redemption of the common shares whereas in the American statutes, some provide for the redemption of preference or special shares while the others are silent on redemption. An exception is the New York Business Corporation Law, 88. 513-515 on which the new Ontario law is based. For a discussion of the problem involved in redemption and the history of the Ontario legislation see Lebovic, Stock Purchase and Redemption Legislation in Ontario, (1968) 26 Fac. L.R. 58.

137 (1938) 2 A.2d 249.

13 Supra, n. 11.

130 Supre, n. 137 at 252.

140 Id. Here the leamed Chancellor is basing his opinion on an obiter statement in Starring v. American Hair \& Felt Co. (1937) 191 Atl. 887, aff'd. (1937) 2 A.2d 249. In this case it was held that where a statute provided for the redemption of special or preferred stock it could not be extended to include the redemption of common stock. This would be the position under Anglo-Canadian law. In Bowman v. Armour \& Co. (1959) 160 N.E. $2 d 753$ the Court upheld the claim of a stockholder who questioned the right of a charter amendment requiring him to accept an earning bond for redeemable preferred shares in lieu of cash. However, the case was criticized in a note by Smalley, (1959-60) 58 Mich. L.Rev. 981.

14 Supra, n. 137.

142 Supra, n. 131.

${ }^{143}$ Here in fact the call on the shares was made so as to retain the past pattern of identifying shareholders with management. This of necessity could not apply to public companies. (See Provisions For Call of Common 


\section{Elimination of the Minority by Sale of Assets to a New Corporation}

In some cases elaborate schemes involving different aspects of company law have been devised in order to eliminate minority stockholders. In Erwin v. Oregon Railway and Navigation Company ${ }^{144}$ the majority stockholders organized a new company and sold the assets of the old company to it for less than their true value. The court did not allow this. One writer has questioned the right to use corporate statutes with the avowed purpose of "freezing out" dissenters or any security holders whom the majority do not care to include. ${ }^{145}$ In the present case the fact that the assets were sold out at lower than their true value may have been crucial in disallowing the scheme. ${ }^{146}$ However, should not the same decision be reached in any case where a new company is set up and the assets sold to it if the sole intention is to get rid of a minority shareholder? This should be the result if the principle in the Greene case ${ }^{147}$ governs.

\section{Elimination of the Minority by Corporate Merger or Consolidation}

If the result of a merger or consolidation is that a shareholder will ultimately be forced to give up his interest in the merged company the court may refuse to approve the scheme even if the shareholder is not immediately removed from the corporation. In Outwater v. Public Service Corp. of New Jersey, ${ }^{148}$ five public utility companies sought to merge. The stockholders of the merged companies would get redeemable nonvoting stock whereas the stock they had given up were noncallable voting stock. Thus, although the stated purpose of the scheme was to enable the merged company to get rid of leases to plants and acquire the fee, the court refused the scheme which they considered nothing less than a forced sale to the majority stockholders at a price fixed by them and payable at their pleasure. ${ }^{149}$

The Outwater ${ }^{150}$ decision was distinguished on the basis of unfairness in the leading case of Matteson v. Ziebarth. ${ }^{151}$

In that case, Ziebarth and Matteson formed a company in which

Stock At Option Of Corporate Directors Sustained, (1955) 103 U. of Pa. L.Rev. 819). However, if this is the case one wonders why the corporation only asked to buy back some of the shares and not all. Both cases also had to deal with the question of restraint on alientation and this may have been the difference. See Greenspoon, A Charter Provision Authorizing Corporation Directors To Call For Purchases at any Time of Shares of Common Stock is Not a Restraint or Alienation and is Valid if Exercised in Good Faith,(1954-55) 43 Geo. L.J. 302.

164 (1886) 27 Fed. 625. See Lattin, Minority and Dissenting Shareholders' Rights In Fundamental Changes, (1958) 23 L \& Cont. Prob. 307 at 312.

145 Lattin, Equitable Limitation on Statutory or Charter Powers Given to Majority Stockholders, (1932) 30 Mich. L. Rev. 645 at 650 .

1s6 In Green v. Bennett (1908) 110 S.W. 108 the majority shareholders of a bank voted to liquidate the bank and sell its assets to a new bank which they formed. The price received was fair. The Court rejected the action of the minority but noted that if what had been done was in effect a consolidation of the dissolved and new bank it would have recognized the right of the minority to get shares in the new consolidated bank. In Theis v. Spokane Falls Gaslight Co. (1904) 75 P. 1004 it was held that a company could not be dissolved and its assets sold to a company formed for continuance thereof in order to get rid of certain minority stockholders.

147 Supra, n. 137.

148 (1928) 143 Atl. 729 , aff'd. (1929) 146 Atl. 916.

109 Lattin, supra, n. 145 at 663 . In summing up Professor Lattin states at 665 that: "Controlling shareholders still have the duty of acting for the best interest of the corporation rather than for themselves alone." This statement is similar to the Anglo-Canadion position. Similarly in Lebold v. Inland S.S. Co. (1936) 82 F. (2d) 351, reheard sub. nom. Lebold v. Inland Steel Co. (1941) 125 F. 2d 369, cert. denied (1942) 315 U.S. 675 (U.S.S.C.) a stockholder received damages where a parent company dissolved a subsidiary and brought its assets in order to get rid of the minority stoclholder in the subsidiaries. See a note on the case by Jaynes, (1953) 28 Wash. L.Rev. 59.

150 Supra, n. 148.

15: (1952) 242 P. $2 d 1025$. 
Ziebarth had a two-thirds interest and Matteson one-third, with one share held by a third party. Things went badly and Ziebarth, who at this stage was the only one taking a working interest in the company, made an agreement to sell the company to Gold Seal Corporation. By this agreement Gold Seal would get the right to use the "Snowy" trademark of the Ziebarth Corporation and manufacture their product. Ziebarth would be employed for eight months at two thousand dollars a month and Gold Seal had an option to purchase all the outstanding shares of Ziebarth. By the time of the agreement Ziebarth had purchased additional shares in the corporation and there were a number of other minor shareholders. At a meeting to approve the agreement Matteson refused and thereafter said he would agree only if he received twenty-five per cent of the sixteen thousand dollars Ziebarth would receive as a temporary employee of Gold Seal. Gold Seal would only enter the agreement if it could purchase all the stock and this prevented the arrangements from becoming operational. Ziebarth then set up a new corporation, Snowy Corporation, and arranged a merger between the Ziebarth Corporation and the Snowy Corporation, which was approved by the directors of both. The stockholders of Ziebarth Corporation received callable preferred shares of Snowy Corporation. Ziebarth also allowed the minority shareholders in Ziebarth Corporation to purchase common shares in Snowy Corporation. ${ }^{152}$

Subsequently, an option agreement between the Snowy Corporation and Gold Seal similar to the original option agreement, including an employment contract for Ziebarth, was concluded. Matteson contested the legality of this merger. The court dismissed his action and this decision was upheld on appeal. The Appeal Court rejected any notion of fraud or unfairness. Moreover, the court held that "this option contract was the only salvation for the hard-pressed Ziebarth Corporation". ${ }^{153}$

Again, this language is similar to that used in the Anglo-Canadian test although not explicitly so stated. One can usefully compare the situation in this case to that which arose in Sammel v. President Brand Gold Mining Co. Ltd. ${ }^{154}$ In both cases there was a virtually insolvent company; in both, the corporations involved could be salvaged by an outside source willing to act only if it could purchase all the stock or shares; both had minority shareholders or stockholders whose shares had to be eliminated and, in both, the effort was successful. The South African case succeeded by internal corporate reorganization while in the American case this result necessitated the setting up of a new company and a merger of the new and old companies. ${ }^{155}$ It is submitted the Anglo-Canadian approach is more convenient especially if

\footnotetext{
152 There was nothing fraudulent in offering common shares to the other minority stockholders as their vote was not necessary to support this merger. However, the transaction was not made "bona fide in the best interest of the company as a whole", under the Anglo-Canadian test, since it discriminated between stockholders although the discrimination was not between the majority and minority stockholders but between the dissenting and non-dissenting minority. Nor did the Court find anything fraudulent in Ziebarth's being employed for eight months. The fact that Gold Seal had an option to hire him for an additional sixteen months indicates his services were essential.

153 Supra, n. 151 at 1034 .

154 Supra, n. 98.

iss It is interesting to note also, that in both cases the dissenting minority did not oppose the earlier part of the scheme, in one case the corporate reorganization and in the other the merger.
} 
for some reason it is necessary to continue the separate existence of the original corporation. ${ }^{156}$

\section{Short Merger Statutes}

Although it has been stated that there is no equivalent in American law to the compulsory acquisition provisions in Anglo-Canadian law, there is one procedure which is rather similar, and in at least one respect, more extensive. Under what is commonly called the "short merger statute", a corporation owning at least ninety-five per cent of the shares of its subsidiary may merge with the subsidiary without the approval of the stockholders of either corporation. ${ }^{157}$ Furthermore, the parent corporation can decide on the method of paying for the stock held by the minority stockholders, as well as make them accept cash for their shares.

In considering the short merger statutes it may be helpful to look at their legislative history. They started with an act of the state of New York which applied short merger provisions in the case of certain utility corporations. ${ }^{158}$ This was necessary to "circumvent the blocking tactics employed by small but belligerent minority interests." 159 The validity of this statute was upheld in Beloff v. Consolidated Edison Co. of New York. ${ }^{160}$ This scheme of corporate reorganization was necessary due to the collapse of utility companies during the depression. In this early type of statute there was a check against abuse, since such a scheme had to be approved by the public utility commissions. Such a safeguard did not apply once this device was available to ordinary corporations. What is interesting, however, is that the origin of such a statute was to prevent oppression by the minority, exactly the stated reason in the Greene Report ${ }^{161}$ for the original English provision.

Although there may have been some doubt, at first, about the right of the parent corporation to force the dissenting minority to accept cash for their shares, ${ }^{162}$ the first decision on such a statute, Coyne v. Park Tilford Distributors Corporation ${ }^{163}$ held that the statute did intend

156 At the time of the original offer by Gold Seal in the American case, Matteson owned slightly more than ten per cent of the shares 80 that had the case occurred in an Anglo-Canadian framework the compulsory acquisition provisions could not apply. However, in the South African case the dissenters before the reorganization also held more than ten per cent of the shares so that at that time the compulsory acquisition provisions similarly could not apply. One may wonder if a Canadian court would approve such a scheme as in the Ziebarth case under S. 137A of the Canadian Corporations Act. The case would probably be decided on the basis of whether the court found it to be "bona fide in the interest of the company as a whole."

157 S. 68A, Model Business Corporation Act. Actually the percentage of approval required depends on the state involved. Similar provisions are found in Arkansas, California, Colorado, Connecticut, Delaware, District of Columbia, Iowa, Maryland, Massachusetts, Mississippi, Nebraska, New Jersey, New York, North Caroliina, North Dakota, Ohio, Pennsylvania, South Carolina, Tennessee, Utah, Virginia, Washington, West Virginia, Wisconsin. The problem is more complicated if the corporations are in different jurisdictions. See Bitter, Jurisdiction of the California Commissioner Over Delaware Short Form Mergers, (1964) 52 Cal. L.Rev. 1016. A similar proposal is contained in the Canadian Task Force Report. See Para. 364 at 121 and section 14.11 of the Draft Act.

158 Stock Corporation Law, Consolidated Laws, c. 59 as amended by N.Y. Sess. Laws 1936, Ch. 778, and N.Y. Sess. Laws 1937, Ch. 815, sections 85(1), (5), (7).

is9 Note, The Short Merger Statute, (1964-65) 32 U of Chi. L. Rev. 546 at 602.

100 (1949) 87 N.E. (2d) 561.

161 Supra, n. 22 at 41.

162 This is significant if one considers that Professor Gower limited the Ghanian section by allowing a digsenting shareholder to always have the option of being paid in shares. One of the bases of his argument was that Americans dislike the idea of being forced to accept cash for their shares. Yet American law itself can in such a situation require a dissenting stockholder to accept cash for his stock.

163 (1958) 146 A. (2d) 785 , aff'd. (1959) 154 A. (2d) 893. This decision was followed in Stauffer v. Standard Brand Incorporated (1962) 178 A. (2d) 311, aff'd. (1962) 187 A. (2d) 78; and Earl Marks \& Co. Inc. v. University City Studios, Inc. (1967) 233 A. (2d) 63. 
the surviving corporation to have such a power. The Court refused to accept the argument that such a provision was unconstitutional.

\section{Comparison of Short Merger and Compulsory Acquisition Under Anglo-Canadian Law}

Although it may appear that the American type statute is narrower than the compulsory acquisition provisions under Anglo-Canadian law since it only applies when a parent merges with its subsidiary, it in fact includes the Anglo-Canadian case and extends beyond it. The Anglo-Canadian provisions only apply in a take-over situation when one company has the opportunity to acquire ninety per cent of the shares of another company (or ninety per cent of the shares it does not already own) and seeks within a strict time limit to force the dissenting shareholders to sell their shares. At the time the acquiring company seeks to make use of the compulsory acquisition provision, the relationship between the two companies is that of parent and subsidiary. Under the "short merger" statute, however, the parent company can merge with its subsidiary and force the dissenting stockholders to sell their stocks at any time, not within a prescribed time limit. Thus, the short merger statute in effect provides the power to expropriate minority stockholders at any time. Thus, in a situation like the Esso Standard ${ }^{164}$ case the minority stockholders could be removed at any time if the companies merged, provided the parent had the required percentage (dependent on the jurisdiction involved) of the shares of its subsidiary. Unlike the Anglo-Canadian situation, however, the original corporations will lose their separate identities. The preservation of the separate identities may be of some importance and this, it will be recalled, was one of the reasons for introducing the provision into the United Kingdom legislation in the first place. ${ }^{165}$

A rather interesting comment on the "short merger" statute was made in a note on the Coyne $e^{166}$ case where the author stated that: "It is difficult to imagine circumstances where a forced exchange of shares would be justified by real corporate needs." $167 \mathrm{He}$ went on to state his belief that, "it is unrealistic to conceive that such a small continuing interest would pose a serious threat to the surviving corporation's welfare or burden its management and flexibility."168 Without denying that there may be some justification for such a view, it is submitted that consideration of the Anglo-Canadian law, and its background, at least may have indicated some of the reasons for such a provision. 169 This might have prevented the author from making such a categorical statement. Indeed, as has been shown, the origin of the American "short merger" statute was to prevent the presence of a meddlesome minority.

\footnotetext{
164 Supra, n. 90.

165 Greene Report, supra, n. 22 at 43

160 Supra, n. 161.

167 Note, Elimination of Minority Share Interest by Merger: A Dissent, (1959) 54 Nw. U.L.Rev. 629 at 637. See Darrell, The Use of Reorganization Techniques in Corporate Acquisitions, (1956-57) 70 Harv. L. Rev. 1183 at 1197 . Here, however, the author did note the benefit of getting rid of a minority stockholder.

${ }^{168}$ Elimination of Minority Share Interest by Merger: A Dissent, supra, n. 167 at 637.

169 Id. at 636. The writer did, however, concede that the section may be valid if: "there are clear and imperative reasons for such an occurrence in terms of the needs of the corporation". Another note on the case in (1960) 74 Harvard L.R. 412 was less critical and did consider the fact that the minority could buy stock in the merged corporation on the market. Moreover, their advantage in remaining in a corporation where management is beyond their reach is questionable.
} 


\section{The Right of Appraisal Under American Law}

As in the Anglo-Canadian case, the burden of proving any unfairness is placed on minority stockholders. However, unlike the AngloCanadian situation, American law provides for the valuation or appraisal of the stock in a much more detailed way, and the Courts are more prepared to ascertain the true value of the stocks. This may seem to be an innovation of American law, but in fact as early as the United Kingdom Companies Act of $1862^{170}$ provision was made for the use of experts to determine the value of shares in one special case. The Act provided that in the case of a voluntary winding up a dissenting shareholder who disagreed with the value allotted to his shares could have the value determined by arbitration. ${ }^{171}$

The basic principle of the right to appraisal is found in the Model Business Corporation Act. ${ }^{172}$ It provides that the shares are to be acquired at the fair value agreed upon by the dissenting shareholders and the corporation. Failing agreement, the court is to fix the value and it may appoint one or more appraisers, "to receive evidence and recommend a decision on the question of fair value."173 Even a decision of appraisers can be disputed by an action in court and the court may either accept the advice of the appraiser or modify his findings. ${ }^{174}$ More important, however, is the degree of detail in to which the court goes in ascertaining the value of the shares.

Such appraisal provisions have been applied in the past in the case where a minority is forced to sell its shares as well as in the case where it is the minority who want to sell their shares after there has been a fundamental change in the company. ${ }^{175}$ Recently there has been an attack on the principle of appraisal and a demand to limit its scope or perhaps to abolish it completely. ${ }^{176}$ One writer feels that the right of a dissenting shareholder to demand an appraisal should be limited to the case where there has been a fundamental corporate change and not merely a simple merger or consolidation. ${ }^{177}$ One possibility is not to give a right of appraisal when the stock can be sold on the market. ${ }^{178}$ In such a situation, however, a stockholder may

170 The Companies Act, 1862, 25 \& 26 Vict. c. 89, s. 162.

171 A similar provision as regards the right to arbitration to determine the value of shares in a voluntary winding up exists today in the United Kingdom, Alberta and Newfoundland. See Companies Act 1948 , 11 \& 12 Geo. 6, c. 38, 8. 287; Companies Act, R.S.A. 1970, c. 60, s. 249; and Companies Act, R.S. NAld. 1952 , c. 168, s. 227 respectively.

172 S. 74 .

173 Id.

174 Tri.Continental Corporation v. Battye (1949) 66 A. (2d) 910, rev'd. (1950) 74 A. (2d) 71; Swanton v. State Guaranty Corporation (1955) 215 A. (2d) 242; and In re Olivetti Underwood Corporation (1968) 246 A. (2d) 800 .

175 See Levy, Rights of Dissenting Shareholders to Appraisal and Payment, (1929-30) 15 Cor. L.Q. 420. It is interesting to note that the author felt it would be unconstitutional to have the right to payment as the only right of a dissenter. See also Lattin. Remedies of Dissenting Stockholders Under Appraisal Statutes (1931-32) 45 Harv.L.Rev. 233; Note, The Right of Shareholders Dissenting From Corporate Combination To Demand Cash Payment For Their Shares, (1958-59) 72 Harv.L.Rev. 132; and Note, Valuation of Dissenters Stock Under Appraisal Statutes, (1965-66) 79 Harv.L.Rev. 1453.

176 Manning. The Shareholders Appraisal Remedy: An Essay for Frank Coker, (1962-63) 72 Yale L.J. 223. The writer in questioning the necessity for such a right, points out that originally it was not introduced to protect a dissenting shareholder but was given to the shareholder in cases where previously he could veto a transaction. The provision has also been attacked as being a very costly procedure. See Wooters, The Dis senting Shareholders' Appraisal Statute: Influence of Cost and Interest Provisions Upon the Efficiency of the Remedy, (1970-71) 50 B.U.L.Rev. 57.

177 Letty, Some Miscellaneous Novelties in the New Corporation Statutes, (1958) 23 L \& Cont. Prob. 343 at 378.

178 This would correspond to the position under s. 100 of the Ontario Business Corporations Act, 19 Eliz. 11 , c. 25, 8. 100, where the right of a Court to intervene in fixing the price of shares in the case of a share holder demanding his shares be bought after a fundamental corporate change, is limited to private companies. 
realize his limited chance of getting a higher price even if he does ask for an appraisal. If however, the market has been depressed by fraudulent tactics it seems that the right of appraisal is a useful way to determine the true value of the stock. Thus no benefit will be achieved by removing the right of appraisal in such a situation. A difficult situation arises where a shareholder is forced to sell his shares for cash. There seems to be no valid reason why he should not have a right of appraisal here. Although Delaware has recently curtailed its appraisal provisions, the right remains in the case of a "short merger" where a dissenting shareholder is forced to sell his shares for cash. ${ }^{179}$

In the case where the stock is not being traded on the market and a stockholder's position will be that of an entrenched minority it seems retrogressive to deprive him of the right of appraisal. There is some authority in the United States for the view that a dissenting stockholder may bring a bill in equity to compel the purchase of his shares even if the statute does not provide for such relief or if the relief provided is inadequate. ${ }^{180}$

\section{A Combined Approach}

At present the Anglo-Canadian system provides a "convenient" method of getting rid of minority shareholders in the case where ninety per cent of the shares of a corporation have been acquired as a result of a take-over. Even prior to the existence of the compulsory acquisition provisions in Anglo-Canadian law it was possible in certain special situations for the majority to force the minority to sell their shares if this was done "bona fide in the interests of the company as a whole."

Today this same test is being used in trying to determine if a takeover is genuine and not merely a device used in order to expropriate the shares of the minority shareholders. In American law this "convenient" method is not available. However, there are alternate methods of eliminating unwanted shareholders. These methods, except for the one provided by the "short merger" statute, also depend on the same test of "bona fide in the interests of the company as a whole" although it may be formulated in somewhat different words. The American law does have the "short merger" statute but this cannot be used if it is essential that the corporate identity of the transferor and transferee companies be maintained. In one sense, the "short merger" statute which allows for the compulsory acquisition of the shares of a minority when a parent merges with its subsidiary is wider than any provision presently found in Anglo-Canadian law in that it is not bound by any time limit. On the other hand, American law provides for a more extensive appraisal process. Ghana has already moved somewhat in this direction and similar suggestions have been made for English law. 181

In Canada a start has been made in this direction by the suggestion

179 Arsht and Stapleton, Delaware's New General Corporation Law: Substantive Changes, (1967) 23 Bus. Law. 75 at 87.90 .

${ }^{180}$ Dodd, Dissenting Shareholders and Amendment to Corporate Charters, (1926.27) 75 U. of Pa. L.Rev. 585, 723 at 735; and Note, Statutory Merger and Consolidation of Corporations, (1935-36) 45 Yale L.J. 105 at 114.

181 Act 179 of 1963 , ss. 234 and 235 . It also resembles the suggestion by Wedderburn, $A$ Corporations $O m$ budsman?, (1960) 23 Mod.L.Rev. 663. The Ghana Companies Code, however, tries to discourage the payment of cash for shares. In the American situation the right of appraisal is being curtailed in just this situation where the shares of one company are offered for those of another. 
in the Task Force Report ${ }^{182}$ that a right of appraisal be given dissenting shareholders in the case where a fundamental corporate change has occurred. This would include the case where one corporation amalgamates with another. The Report, however, would also eliminate the right of compulsory acquisition of the shares of a dissenting minority shareholder. This, it is submitted, is a wrong approach to the problem.

It is submitted that had the Task Force on company law investigated and compared the methods of eliminating minority shareholders in Anglo-Canadian and American law, as has been attempted in this article, the convenience of the Anglo-Canadian approach would have been recognized. Yet, the Anglo-Canadian approach is defective in not having a comprehensive right of appraisal. It is ironic that at a time when the right of appraisal is being somewhat limited in the United States, the Canadian Task Force should suggest a comprehensive appraisal right while at the same time eliminating a feature of Canadian law which has been recognized as having some merit. ${ }^{183}$ This is not to suggest that the right of appraisal should not be adopted into Canadian law. On the contrary, it is submitted that such a right should be provided for. The compulsory acquisition provision should be retained while at the same time the dissenting minority should be granted a right of appraisal not only in the case where they are forced to sell their shares but also in the case where they would force the company to acquire their shares. If this were done, Canada could combine the convenience of compulsory acquisition with the benefits of a genuine appraisal system and thus have the best of both worlds.

102 See the Report, Proposals for a New Business Corporation Law for Caneda, Para. 364 and 373 at 121 . 123 and 8s. 14.11 and 14.17 of the Draft Act.

${ }^{183}$ Memorandum by Davis, Polk, Wardwell, Sunderland and Krendl prepared for the Jenkins Committee and found in, Minutes of Evidence Taken Before the Company Law Committee 1070. British Columbia, which is also in the process of revising its company law, would still allow for the compulsory acquisition of the shares of a dissenting minority shareholder but would give the court specitic authonty to "hx the terms of payment". See Bill 66, Companies Act, introduced in the British Columbia Legislature on April 7, 1972 at 8. 281 and s. 281(4)(a). 